\title{
5.3 The development of future agrobiologists' foreign language communicative skills
}

Nowadays it's important to develop communicative skills for the representatives of different technical and agrobiological specialties meaning future agrononomists and specialists in biotechnologies to be with no doubts very perspective trends of higher educational establishments students' training among others.

According to recent investigations the professional communication skills formation is correlated with the elaboration of adequate behavior style and interaction with colleagues, tolerance, understanding to conclude the atmosphere of respect, reliance for the productive professional and social mobility either in class off-line or distant online regimes involving the resources of professional language Moodle platform courses sources [411], [412].

However the most of researchers do not concretize the means to be applied to reach such aim during the work with technical foreign texts on the practical lessons of professionally oriented English for agrarian engineers. They used to know that technical scientific literature is mostly to be studied in the aspects of its informative contest, logicality, objectivity etc [414].

Basing upon the experiment to be conducted within the National University of Life and Environmental Sciences of Ukraine in the first 2021/2022 studying year term including participation of bachelor's degree program 88 students from the Agrobiological Faculty and the Faculty of Plant Protection, Biotechnology and Ecology there are some conclusions and the adequate samples to be noted in our following report to spread our previous conclusions concerning main stages to develop future agrobiologists' foreign language communicative skills while adding some following seven stages- steps (familiarization and narrowing of the actual professional topics to general one, at which simultaneously several reports are prepared; clarification of the plan, vocabulary, key questions and answers of each of the participants in the future dialogue to avoid coincidences; preliminary formal general dialogue start with constant colloquial cliché; the actual entry into the dialogue 
according to a specific topic; providing dialogue with the elements of the discussion; a reversible asking to specify unpublished pre-prepared items; the formal general ending of the conversation with the stable conversational clichés) with the eighth stage of philological word to analyze the professional terms.[414]

The experience to involve the above named algorithm may be considered to be successful because of the adequate questionnaire in which students evaluated such experience as positive to adapt them to foreign speech.

In order to conduct such experiment some adequate scientific practical methods like explanation, specialized terms and communicative schemes acquaintance, studying the algorithm of action, discerning of terms meaning, stimulating of communicative motivation etc. were applied.

The first conclusion deals with the statement that the future agrobiologists successfully used to develop their communicative skills through important previous traditional tasks which gave background for creative tasks.

We consider that no students' foreign speech developing can not do without concluding some dialogues which combine real life situation and professional agrobiologists' speech or biotech professional terms explanation after working thematic materials manuals out as well as familiarization with basic communicative intentions phrases as well as grammar material repetition involving biological thematic enrolment like recognition of modal verbs, if-clauses, passive voice or other grammar phenomena in some statements like «....The skilled agronomist must check the degree of fruit maturity without faulties....All people must, had to and we'll be to get life vigor to survive like seeds...You ought to soak seeds in water overnight....You can, could and will be able to end dormancy of these seeds...It may, might and will be permitted to be too cold for seeds to germinate...If he comes, we will together cover seeds while soil raking... When he came, we would together cover seeds while soil raking....A new seed variety is improved by him.... Sowing methods are improved by our agronomists every season. ....They were improved by him last spring. ...Consumer's interest in bulk order will be improved by them next autumn...Buds are always cut before they flower by him.... Sowing methods are improved by us....The 
situation with seed aeration can be improved by me» etc or answering thematic questions like «What is biotechnology and what are its colours? How can genetically modified organisms help farmers? How do consumers feel about genetically modified organisms in your country? What does biotechnology deal with in general? What nonfood products come from plants? Why is good soil important? How do farmers plant seeds? What do seeds need to grow? How do plants change as they grow? What function does each part of plant serve? What are the main agricultural operations? What are agricultural crops to add fruit and vegetables categories?» or filling gap exercises up like «increasing the size of a harvest is ... and...is a test of the effects of a product the ability to use minimal nitrogen is...and ...is able to withstand dryness organism produced by genetic engineering is... and b...... can resist herbicides. Laboratory ... suggests that the product is safe.... seeds counter pest population and... seeds let farmers kill weeds. Scientists are enhancing desirable... and some farmers prefer...to GMOs.... is the appearance of a trait and...making a copy of an organism....is a segment of DNA and ... is a banning something....is altering genetic material and... having artifically introduced genetic material....can create stronger anomals and there is a strict $r$......of genetic research. There are many... about cloning and Robert wants to work in the... field, ....A crop that grows underground is... and ... is a crop to produce grain,... is a material made of small pieces of rock and mineral and... is a material that is deposited by water. Those... will grow into flowers and plants absorb nutrients from the soil with their.... and...is a strong plant that is grown for its seeds.......is a substance added to improve soil and...is a method of scattering seeds, .... is a crop that has pods and... is crops that have been gathered....is rock and mineral that eventually form soil and is the size of particles in a soil.... The farmer used...to improve soil and the weeds died after Mary used.......It is still too cold to plant the seeds- the ... is 25 degrees.... is a type of large sweet fruit and... is a group of farmers selling crops....is a firm outer layer of a seed and to... is to sprout from a seed....During droughts the...can be blown away by strong winds and the farmer was pleased to have 90 percent... of newly planted crop...The field's... is 10 pounds per 
acre and each plant has a different number of days until it can be harvested...» etc.[414]

It's worth to say that the theoretic above named tasks are necessary as the background of the further creative tasks as well as concluding own sentence concerning different grammar rules with the used professional terms words representing of which may be introduced in two ways.

The first of such ways is mentioning only English variant predicting further English explanation like crossword concept definition exampling such English variants as genetic engineering,transgenic organism, biotechnology application, gene enhancement, regulation, plant traits, herbicide-resistant, animal performance assessment, conventional seed, GMOs, insect-resistance, yield enhancement, nitrogen efficiency, weeds, biotech seed) or mentioning native language parallel variants (like acidity- кислотність, abundance- велика кількість, to adjust- регулювати, against pests- проти шкідників, agriculture - сільське господарство, agricultural operations- c/2 dï̈,amendmentпокращувач, animal husbandry-тваринництво, апnиаl- щорічний, annualsоднорічні рослини, aromatic variety- ароматний сорт, barley - ячмінь, to beat fruit- плодоносити, beеt- буряк, bitter variety- гіркий сорт,blossom- ивіт, branch- галузь або гілка, broadcast seeding-трансмісійний висів, biennialsдворічні рослини, buckwheat -гречка, bud- брунька, to bиy-купувати саbbageкаnуста, cauliflower- иявітна капуста, сапе-стебло або тростина, cellклітина, cereals- зернові, clay- глина, combine harvesting- механізоване збирання врожаю, to change- змінювати, to check - перевіряти, to check weedy growth- здійснювати стримуючий вплив на рicm бур'янів, to chooseобирати, to соver- покривати, сrор rotation - сівозміна, coulouring intensityінтенсивність забарвлення, сrop growing- рослинництво, cross-pollutionперехресне запилення, сrисіfers- хрестоцвіті. сиситber- огірок, сrитb and peel density- щільність м'якуша і шкірки, to deal with- мати справу з, to demand- потребувати, dense- щільний, to determine-визначати, dill-кріn, to dig- копати, disease -хвороба,draught- resistant- посухостійкий, to dry out- 
висушувати, emergence- поява сходів, eggplant- баклажан, farmer's incomeприбуток фермера, to favour-сприяти, fertile- pодючий, fertilizingудобрення, fertilizer- добриво,fodder plants- кормові рослини, garlic-часник , to germinate- проростати,grain crops- зернові культури, grains -зернові культури, greепhоusе- теплиця, to grow-вирощувати, hard coat- икарапупа, harvest - урожай, to harvest- збирати, horse-raddish - хрін, horticultureсадівництво, hоse- иланг, hotbed- парник, hое- сапа, to hoe- сапувати, immature- незрілий, іпосиlate- щзепити, irrigation- зрошення, leguтеs- бобові, liquid- piдина;lime - вапно, loam- суглинок, тапиre- добриво, marshy заболочений, miscalculation- хибні розрахунки, to тіх- змішувати, таrrow, mature-дозрілий, nutrients- поживні речовини, onion- цибуля, oat- овес, to overwinter- перезимувати, parsley- петрушка, реа- горошина, реапитapaxic, peаch-персик, perennials- багаторічний, persipitation- onaдu, plant density- щзільність насаджень, plum- слива, pear- груша, pest- шкідник, picking time- час збору урожаю, to plant-садити в землю, plot- город (присадибна ділянка), plowing- оранка, pod-стручок, рот-вазон (горичик), pollution- забруднення або запилення, powder- порошок, роwns- пасльонові, to predict- передбачити, to prevent- запобігти, to рrипе- обрізати гілки, raddish- редuc, rainfall - достатня кількість опадів, rainfall -fed вологолюбивий, rake-граблі, to ram-утрамбувати, to release-розпушувати, to rake- згрібати. resistant- стійкий, to ripe- дозрівати, ripening proofознака стиглості, ripen- дозрілий, root-корінь, root out-викорінювати, rowрядок, гуе- жито, sеed- насіння, seеdbed- рілля, seedbed preparationnідготовка до посівної, seed drill- точний nociв, seedling, silt, sowing methodsметоди посіву, soil- грунт,shoot- паросток, shoot gapping- проріджування сходів, ), to soak- замочувати, to sow-сіяти,spade-лопата, spider plantповзуча рослина, spraying- обприскування, sprout- проростання, stemстебло, straw- солома, sulfur- сірка, to support- niдтримувати, surfaceповерхня, tangerine - мандарин,tillage -обробіток грунту, tор- гичка, tор soil- поверхневий шар-грунту,tuber- бульба, vine plant- в'юнка рослина, 
water-вода,to water- полити, weed- бур'ян, wheat- пшениця, windraw harvesting- немеханізоване збирання врожаю,winter-killing- вимерзання , winter wheat- озима пшениця, towithstand-витримувати, yield-yрожай yield growth- приріст урожайності, thallus - слоевщще (одноклітинне, багатоклітинне або диферениійованне на клітини тіла водоростей, грибів, лишайників, та подібних)ропdscum - ставкова піна,tissuе - павутина або тканина,отnivore - всеїднаістотарира - лялечка,отпіvorous всеїдний,algae - водорості, bivalve - двостулковіоffspring - виплід,nисleus ядро,larva - личинка,kelp - ламінарія,hibernation - зимова сплячка, greenhouse effect - парниковий ефект,to hatch - вилупитисяtentacles щупальияя ,flock - зграя, natural selection - природний відбір,embryo ембріон, diversity - різноманітність, cell - клітиннаabsorption - поглинання binary fission - подвійне диханнясhloroplast - хлоропласти,deciduous plant листяна рослина,cloning vector- вектор клонування,DifferentiatedCells диференційовані клітини,DNA Sequencing- секвенування ДНК,Gene Cloning - клонування генів,Genetic Engineering-генетичнаінженерія,Gепе Expression-експресіягенівGenetically Modified Organisms- генетично модифікованіорганізми,TransgenicAnimals-трансгенні твариниShort Tandem Repeats (STRS)-короткі тандемні повториIn vitro Mutagenesisмутагенезін-вітро, NuclearTransplantationядерна трансплантаціяPolymerase Chain Reaction (PCR)-полімеразно ланцуюгова реакиія,Recombinant DNA-рекомбінантна ДНК Restriction Fragmentsфрагменти обмеження, enzyme-linked immunosorbent assay (ELISA)імуноферментний аналіз,Insect-resistant crops-cmійкі до комах культуриMolecularbiology-молекулярнабіологія,Plantbreeding-селекція рослин,Plantpests-икідникирослин,Selective Breeding-вибіркове розведення,Insecticide resistance-стійкістьдоінсектицицівGeneflowпотікгенів,Agricultural Biotechnology-c/2 біотехнологія, Allelicexclusionалельневиключення,aminoacid-амінокислота,acetic-yксусна кислота,washing - мийний засіб,vortex - вихрова мішалка, alcohol - 
cпирт,algae - водорослі, lactic-acid-молочно-кислі бактерії, callus - калюс ,catabolism - катаболізм, cellcultured - культивованакультура клітин, daтаge - пошкодження, diploid - диплоїд, писlear - ядернаДНК, donation віддача, передача, adverse effect - несприятливий, ехоп - екзон, extraction екстракиія,feature - особливість,industrial - промисловий,file - pяд, flask колба, склянка, foodstuff- продовольство, харчові продукти, fungus - грибок, genеsis - походження ,gепоте - геном,теssenger- перенощик еtc.

The choice of the way to represent terms depends upon the level of students' audience and is personally oriented [413].

The background of our further research concerning biotech students' and future agronomists' speech deals with our previous investigations being dealt with the formation of foreign communication culture of the future agrarian engineer to be fulfill in several stages concerning text «Vehicle parts» [414].

Thus we remember that firstly it was a need previous exercise block to be proposed for student's first steps to enter the system of own communicative intentions and reactions through own version presentation and exchanging the reactions with other group-mates. For that purpose the students had to analyze the existing and no existing Ukrainian- English equivalents. At the end of such work we'd recommend to exchange the notes with the done exercise with imaginable colleague to check the another student's answers basing upon the keys- correct answers(to be proposed by scholar) and to comment the accuracy or mistakes using the communicative schemes «Comments and Reactions».

Positive comments were represented in such helping start of phrases as «This work is proper», "You are well done», "No mistakes», «Without negative comments», «Excellent! I have never seen better work than this one ».

Negative comments were represented with such schematic statements as «This work is good in general but pay attention on...», "I noticed only such mistakes in...», «I'm afraid you are mistaken in...», «Please, try to improve... », «Excuse me but be more attentive in ...». 
Working with such communicative schemes we'd pay attention of future engineers on the importance to use some tolerant negative comments and adequate tolerant reaction on them like "Thanks for your comments», "I'll do the best to improve...», "I 'll pay attention on ...», "I'll be more attentive in future...», «I promise I 'll improve these mistakes».

Besides it is in place to stress on need to convince the interlocutor of his thoughts and troubles understanding basing upon usage of communicative scheme «Positive results hope and Understanding». Positive results hope might be expressed through phrases «Don't be afraid! Everything will be done in time», "You'll get all you've planned 》, "We'll do the best to help you», «Your problem will be solved», «You'll reach your aim». Understanding dealt with the usage of such statements as «I hear you!», "Your problem is important for me», "I have enough time to discuss your problem», «Share your troubles», «I understand you», «We'll seek convenient solution for both of us», "Don't be nervous. We'll find the way».

In order to add our future practical observation of the biotech students and future agronomists dealt next stage of previous studying and practical usage of the technical text term system was the task to read, to translate and to add the missed abstracts of the text «Vehicle Parts» too: «There are different types of .... internal combustion engines, external combustion gins, hybrid, steam or jet ones. Let us describe the internal combustion one. Internal combustion is the process of ... within the engine combustion chambers. Stationary engine parts are the cylinder block, the crankcase and the cylinder head. The cylinder block is one of the basic ... of the engine. Rotary engine... are the crankshaft, the flywheel and the camshaft. The crankshaft changes reciprocating motion of pistons to rotary motion. The camshaft opens the valves of the engine. Reciprocating engine ... are pistons, valves, rings and connecting rods. These ... cause engine vibration. The piston moves up and down within the cylinder. The rings provide ...compression for the piston. The valves open and close the combustion chamber where the burning of fuel takes place. The connecting rod links ... There are four separate ... of engine: electrical, fuel, lubricating and cooling. The gasoline engine has no pump but carburetor to transmit mixture of fuel and air to ... . Oil pumps 
of ... kinds provide lubrication. The oil filters reduce engine wear. The strokes of ... are intake, compression, power and ...».

After that work future agrarian engineers started to express own agreement ( $I t$ is true », «It's correct», "I agree », "I 'm glad to support the thought about...», «I 'm glad to support the statement about...») or disagreement (Sorry, but it seems to be false», «Sorry, but it seems not to be correct», «Sorry, but I must disagree», «I'm afraid I can't support the thought about...», «Sorry, but I can't support the statement about...»).

We'd recommend to regard the previous tasks as the stage to prepare any future biotech student a and future agronomist's foreign speech development in close connection with the task for agrarian engineer to choose redundant and combining terms and to represent his choice for the discussion through «Model: Look! I think that the word to be missed is «crankcase» (№1). Also I think that the word to combine meaning of others is «systems» (№5). Am I right?».

To fix the usage of terms system in own speech was fulfilled through the set of questions to be asked (1. What are the kinds of engines? 2. What are the main parts of internal combustion engine in general? 3. What is internal combustion? 4. What are strokes of internal combustion engine? 5. What are systems of internal combustion engine? 6. What do oil filters do? 7. What are titles of various engine parts? 8. What are titles of various parts of vehicles?) with the possibility to discuss separate version in collective body using the model «Internal combustion is the fuel burning within the engine (№3). Am I right?».

The mentioned work might be in the form of creative retelling or own separate versions representation to be further generalized in subgroup reporting dialogue starting from the first adaptive versions up to the complicated improved samples.

To illustrate such statement we'd propose student works exampling topics «GMO», «Biotechnology» as well as «Seeds», «Soil» or «Plant Growth» on the basis of foreign writer's book «Agriculture» to be fixed in two e-learn courses to be placed on Moodle platform [413], [411], [412]. 
There were several variants to introduce «GMO» topic in some dialogues varieties.

The first sample of «GMO» topic dialogue deal with such replicas as «-Hello. Hello. - How are you doing? - Great, I after all got a cat, moreover as two catsWhat did you call it? -V and Tani- Such interesting names- What's about you?Also great, on weekends I want to go out of town to friends-That's coolWhy did you get me? - I wanted to discuss a few issues with you.-Oh, great -So, what are the challenges of agricultural bioengineering?

Well consumers fear that genetically modified foods are not safe-Should not people be worried a bout eating genetically modified food? - Notatall. The science says that genetically modified food is safe to eat. We just need to do a better job of communicating this with the public. -What do you think will happen? - We need to educate the public about genetically modified foods? In some countries consumers have been very vocal. We have responded by increasing their regulation of agriculture. In some cases, they have responded by prohibiting all genetically modified products. This is not what we want to be.- Of course not. Thank you for the conversationThank you, too- You want to go to lunch with me? - Yes, with pleasure.- Good then at 1 a.m. in the lobby-Ok, See you soon-Bye- bye» or «-Hello. What brought you here?: Hi. I came to you to tell you about my invention.- Carol, please come in. I understand your new seed is almost readyformarketing.- $\quad$ It is. After the animal performance assessments, it will be ready to go.- Wonderful. Tell me all about it I want to know the best way to advertise it.- Well, the main benefit is that it's extremely drought-resistant Okay. So we'll do well selling it to farmersindryregions.- Yes. We'll target talials where rainfalls are unpredictable.- Okay. What else?We should emphasize the dependability of our seed.

Tests showed that the yields produced during rainy seasons and those produced $d$ uring droughts varied very little and they're better for the environment than conven tional seeds.- How?- With fewer crops failingduring drought seasons, 
there'll be greater yields. That means this land will the used per season.- Excellent, Carol.- Can you sell my seeds as the mostexpensive?-Of course, the development is very good. I 've already known who to offer your invention to.Thank you. Goodbye!- Goodbye!» or "- Good day, how are you? - Good day, I'm fine. And you?-I'm fine too. What are you going to do now? Do you have a little time for me?- Oh, I'm going to drink a cup of coffee. - Fine! Can I have coffee with you and ask a few questions?- Of course. I will be glad.- So, what are the challenges of bioengineering?- Well, consumers, because of their ignorance and each of interest just fear that genetically modified foods are not safe.-So, you consider that people shouldn't be worried about eating genetically modified food?- Exactly. The science says that genetically modified food is safe to eat. We just need to do a better job of communicating this to the public.- What do you think will happen if you don't educate the public about genetically modified foods? - If some countries consumers have been very vocal. Some governments have responded by increasing their regulation of agriculture, what is not correct in some cases, they've responded by prohibiting all genetically modified food what made people believe that they were right and this products are dangerous. This is not what we want to happen.- Of course not! I'll take care of it, so my company will. You' re hired, I need more employees like you.- Thanks, I appreciate that. I'll do my best.- Hope so, I have great plans on you, don't disappoint me.- Ok. Sorry, I don't have any more free time.- That's ok. Good bye!-Good bye!» as well as: Good day, how are you? - Good day, I'm fine. And you?- I'm fine too. What are you going to do now? Do you have a little time for me?- Oh, I'm going to drink a cup of coffee -Can I have coffee with you and ask a few questions?- Of course. I will be glad.- So, what are the challenges of bioengineering?-Well, consumers, because of their ignorance and each of interest just fear that genetically modified foods are not safe.- So, you consider that people shouldn't be worried about eating genetically modified food?-Exactly. The science says that genetically modified food is safe to eat. We just need to do a better job of communicating this to the public.- What do you think will happen if you don't educate the public about genetically modified foods? - If some countries consumers have been very vocal. Some governments have responded by 
increasing their regulation of agriculture, what is not correct in some cases, they've responded by prohibiting all genetically modified food what made people believe that they were right and this products are dangerous. This is not what we want to happen.Of course not! I'll take care of it, so my company will. You' re hired, I need more employees like you

The second sample of «GMO» topic dialogue deal with such replicas as «- $\mathrm{Hi}$, do you know any professional concepts definitions?-Yes, I can tell you that fusion proteins or chimeric (kī-'mir-ik) proteins (literally, made of parts from different sources) are proteins created through the joining of two or more genes that originally coded for separate proteins. Translation of this fusion gene results in a single or multiple polypeptides with functional properties derived from each of the original proteins. Recombinant fusion proteins are created artificially by recombinant DNA technology for use in biological research or therapeutics. Chimeric or chimera usually designate hybrid proteins made of polypeptides having different functions or physicochemical patterns. Chimeric mutant proteins occur naturally when a complex mutation, such as a chromosomal translocation, tandem duplication, or retrotransposition creates a novel coding sequence containing parts of the coding sequences from two different genes. Naturally occurring fusion proteins are commonly found in cancer cells, where they may function as oncoproteins. The bcr-abl fusion protein is a well-known example of an oncogenic fusion protein, and is considered to be the primary oncogenic driver of chronic myelogenous leukemia.-Thanks, I appreciate that. I'll do my best. - Hope so, I have great plans on you, don't disappoint me.- Ok. Sorry, I don't have any more free time.- That's ok. Good bye! -»

The third sample of «GMO» topic dialogue deal with such replicas as «- Hello. How are you? - Not bad. Are you ready to start an interview?- So of course, I want to talkmore about genetically modified food - So, what are the challenges of agricultural bioengineering? - Well, consumers are scared that genetically modified food is not safe.- Should people be worried about eating genetically modified food? - I think that fears are in vain. The science says that genetically modified products safe to eat. 
We just need to do a better job of communicating this with the public .What do you thinkwill happen if you don't educate the society about genetically modified foods?

In some countries consumers have been very vocal. State establishments there responded by increasing their regulation of agriculture. In some cases they have responded by prohibiting all genetically modified prod ucts. !- Thank you for the interview. It was a pleasure to talk about an important topic today. -Which kicks the whole world.Thank you too. It was nice to spend time. See you! - Bye!» as well as «-HelloHello Carol, please come in. I understand yournew seed is almost readyf or marketing. -Yes, it is. I agree. After the animal performance assessments, it will be ready to go.- $\quad$ Wonderful. tell my all about it. I want to know the best way to advertise it.- Well, the main benefit is that it is extremely drought-resistance- Okay. It is well for farmers in dry regions.- Well done for inventions .-I have another question: how long have you been working on this product.-About three years- Oh, that's cool-Thanks and I suggest going to the café for lunch and and discussing a few more details. -Well then meet at 2 p.m - Okay, see you.-Bye»

The fourth sample of «GMO» topic dialogue deal with such replicas as ««Please come in- Hi. Do you have some time to listen to me?- Yes of course. I understand your new seed is almost ready for marketing.- It is. After the animal performance assessments, it will be ready to go- Wonderful. Tell me all about it I want to know the best way to advertise it.- Well, the main benefit is that it's extremely drought-resistant - Okay. So we'll do well selling it to farmers in dry regions.- Yes. We'll target talials where rainfalls are unpredictable.- Okay. What's else? We should emphasize the dependability of our seed. Tests showed that the yields produced during rainy seasons and those produced during droughts varied very little and they're better for the environment than conventional seeds.- How?- With fewer crops failing during drought seasons, there'll be greater yields. That means this land will the used per season.- Excellent, Carol.- Do you think my invention will be in demand in the market? 
- Of course, your seed has great prospects, but it needs a little refinement. - And how do genetically modified organism help farmers? - We can improve the necessary characteristics in the organism, exampling these seed. Well, the main benefit is that it's extremely drought-resistant. - Okay. So we'll do well selling it to farmers in dry regions.-Yes. We'll target areas where rainfalls are unpredictable.-Okay. What else?We should emphasize the dependability of our seed. Tests showed that the yields produced during rainy seasons and those produced during droughts varied very little and they're better for the environment than conventional seeds.-How? - With fewer crops failing during drought seasons, there'll be greater yields. That means less land will be used per season. - Excellent, Carol.- Can I get any award?-Yes, you can. I give you some free days to have a rest».

Thus the discussing plant products gave basic three version students' dialogues.

It's worth to say that the above named GMO discussing attracted attention to the wide spread topic of not only scientists but every country social community too as well as discussing the role of biotechnology as the to the modern perspective biological science. That was the reason to introduce «Biotehnology» topic in several dialogues varieties too.

The first variant of «Biotechnology» topic dialogue deals with such replicas as «-Hello, nice to meet you-Hi, nice to meet you too. Can I help you?- Yes, you can. Let us discuss real life story concerning biotechnology. I agree, with pleasure. What real life story do you mean? - Well, listen. Once upon a time, scientist Tim decided to take a weekend job because he had been busy writing a science paper, "The Endangered Species», last week. In it, he explored the process of the aclosing butterflies. There are a lot of unfinished tasks in the laboratory. Firstly, he checked the state of the new pea species that his $l$ aboratory had developed.The scientist determined that the plant had entered declev ation phase and the symptoms of $a$ mosaic disease also appeared. So he decided to give drugs and fertilizers. but got tired and went home for a rest.Oh, it's interesting. And what professional terms did you apply in it? 
For example drugs means chemical substances that can change how organism wo rk and fertilizers mean natural or synthetic origin that is applied to soil or to plant tis sues to supply plant nutrients. Other terms are to be specified.-

Thank you for explanation. May I ask you more?- I'm afraid not. I'm short of time. We need to postpone our conversation.- OK, see you later. -Bye»

The second variant of «Biotechnology» topic dialogue deals with such announcement:«-Hello, nice to meet you?-Hi, nice to meet you too. Can I help you?Yes, you can. Let us discuss real life story concerning biotechnology. -I agree, with pleasure. What real life story do you mean? - Well, listen. Once upon a time, scientist Tim decided to take a weekend job because he had been busy writing a science paper, «The Endangered Species» last week. In it, he explored the process of the aclosing butterflies. There are a lot of unfinished tasks in the laboratory. Firstly, he checked how the new pea species that his laboratory had developed was doi ng.The scientist determined that the plant had entered declevation phase and the sym ptoms of $a$ mosaic disease also appeared. So he decided to give in drugs and fertilizers. To improve the condition of the plant that was under threat.-Oh, it's interesting. And what professional terms did you apply in it?- I applied such terms as «fertilizers», «drugs» as well as «declevation» phase. What do these biotech terms mean?- For example «drugs» mean medical substance being used to treat some adequate disease and «fertilizers» mean substances to improve plant nutrition.-And what do you know about a fusion gene?Well, it is a hybrid gene formed from two previously independent genes. It can occur as a result of translocation, interstitial deletion, or chromosomal inversion. Fusion genes have been found to be prevalent in all main types of human neoplasia. The identification of these fusion genes play a prominent role in being a diagnostic and prognostic marker. - Other terms are to be specified.- Thank you for explanation. May I ask you more?-I'm afraid not. I'm short of time. We need to postpone our conversation.-Ok, see you later.-Bye». 
The third versions of dialogue to discuss biotechnology may also be represented as the following statements: «-Hello, nice to meet you.-Hi, nice to meet you too. Can I help you?-Yes, you can. Let us discuss real life story concerning biotechnology.-I agree, with pleasure. What story do you mean?-Well, listen. Once upon a time I attended lecture and learned a lot about biotechnology. Now I know that biotech specialists use living biological organisms, their systems, processes and genetic material, applying scientific methods of genetic engineering, in order to create new varieties of products, plants, vitamins, medicines, as well as improve the properties of existing species in plant and animal environments that are resistant to unfavorable climatic conditions, pathogens and diseases. In medicine, biotechnologists play an invaluable role in the creation of new drugs for early diagnosis and successful treatment of the most complex diseases. -Oh, it's interesting. And what professional terms did you apply in it?-I applied such terms as "genetic material», as well as «pathogen» and «genetic engineering». -What do they mean?-For example «pathogen» means a biological agent that causes disease in another host organism and «genetic material» means carrier of genetic information of any organism. Other terms are to be specified.-Thank you for explanation. May I ask you more?-I'm afraid not. I'm short of time. We need to postpone our conversation.-OK, see you later.-Bye»

The fourth variant of «Biotechnology» topic dialogue deals with «Hello, nice to meet you.-Hi, nice to meet you too. Can I help you?-Yes, you can. Let us discuss real life story concerning biotechnology. - I agree, with pleasure. What real life story do you mean?- Well, listen. Once upon a time my mother and I used to be in Kyiv and we went to a biotechnology laboratory. There I became interested in all the processes, but I liked watch the creation of stem cells. most of all -Oh, it's interesting. And what professional terms did you apply in it? I applied such terms as «stem cells» as well as «cryofreezing» and «differentiation»-Can you give one definition?-Yes, I can.-For example «stem cells» are non-specialized cells that can be used on any cell-Thank you for explanation. May I ask you more?- Yes, you may/-So what are the challenges of agricultural bioengineering? - Well consumers fear that genetically modified foods are not safe.- Shouldn't people be worried about eating genetically modified food? - Not at 
all. The science says that genetically modified food is safe to eat. We just need to do a better job of communicating this with the public. - What do you think will happen if you don't educate the public about genetically modified foods? - In some countries consumers have been very vocal. State structures there have responded by increasing their regulation of agriculture. In some cases they have responded by prohibiting all genetically modified products. this is not what we want to happen. - Of course, not!Thank you for the interview. It was a pleasure to talk about an important topic today. Which kicks the whole world.-Thank you too. It was nice to spend time.-Thanks for answer. See you!- See you later.-Bye!».

As it was shown some above named samples directly combined real life stories with professional terms definitions.

Besides represented version we'd like to represent such interview between. interviewer and speaker as the fifth dialogue concerning with biotechnology «- So what the challenges of agricultural bioengineering?- Well consumers feel fear that genetically modified products are dangerous for our body. Shouldn t people be worried about eating genetically modified food?- Not at all. With recent research, scientists have proven that genetically modified food is safe to eat. We just need to do a better job of communicating this with the public.-What do you think will happen if you don`t tell the whole truth about genetically modified foods? - In my opinion, at present people are not ready to take modified products as something ordinary, but see it as a threat. The government is also not informed about GMO. In some cases, they have responded by prohibiting all genetically modified products. This is not what we want to happen. -In some cases, they have responded by prohibiting all genetically modified products. -But what are basic concepts about plants to be further used while biotech investigations?- For example, I 's like to know about wild and cultivated plants, something about tropism, why plants store starch, reproduction, the use of sunlight by plants for photosynthesis etc. exampling definition of «tropism» as reaction of movement to the stimulus and starch-Thanks for you being interviewed.-See you later.Bye»

Thus the discussing biotechnology gave basic four version students' dialogues. 
It's worth to say that GMO and biotechnology became important for discussion but such discussion was mostly related to the second year students' interest. The adaptive period being related to freshmen demanded search of the more common topics for conversation starting from the agricultural products and processes discussion. That was the reason to unite basic idioms from agronomists' professional speech and communicative intentions for the topic «Plant products and processes» exampling some dialogues .

The first version to discuss plant products may be represented in the next dialogue: «- Hello! Welcome to the farmer`s market. Can I help you with something?Hello! Yes, you can. I want to buy fresh fruit from you.- What fruits are you interested in? = Oranges, apples and strawberries.- These fruits are perfect, we only picked them yesterday.- Oh, that's good! I would also like to buy some potatoes. How much does it cost?- One kilogram costs one dollar.- Good. I will take 3 kilograms.- What else are you interested in?- I saw an ad for you selling cereals. Do you have it?- Yes, we grow cereals on a neighboring farm. What cereals are you interested in?- I need buckwheat and wheat.- It's nice choice-I am interested in the following question.- What exactly?How is your farm preparing for the field?- On our farm fields are prepared for a few months leading up to planting. Fields are tilled with tractors, plows and field cultivators. This softens the soil and aerates it. Fertilizer and nutrients are also added. Weeds are removed through tilling and the use of herbicides.-Thank you for the interesting information!-Total Price: 20\$.-Thanks for your help! Goodbye!Goodbye!».

The second version of dialogue about plant products may be represented in following sample: «Good afternoon! You have such beautiful watermelons! -Oh, yes, these are the best watermelons in Ukraine, brought from the Kherson region -Wow, that's cool! How much do they cost? 5 UAH per kilogram - Can I taste? - Yes, of course, help yourself, please.-Wow, what a delicious and juicy watermelon. Apparently, a lot of effort was involved in growing these watermelons.- Oh yes, firstly farmers sowed seeds and planted plants into the ground, watered, sprayed, weeded, as well as they raked, harvested yield, and now they brought all products to our market.- I can give 
you 3 watermelons for 4 UAH per kilogram. Thanks, let's have three . I'll weigh it now! ... three watermelons weigh 21 kilograms, so 84 UAH are from you.- Here they are, take it, thank you! - Thank you too! we have a wide range of products to attract your interest Yes, I see that you have potatoes, onions, cabbage, tomatoes, zucchini, and all this at a good price, but I'm short of money! No problem, welcome to as next time! Have a nice day - You too, see you later, goodbye».

The third version to discuss plant products may be represented in such dialogue as «-Good afternoon. May I help you-Yes, please. I'm looking for a nice feed for my pigs and chickens. Is there anything not expensive?-For pigs I can offer beet of varieties or carrot as well as millet or maize.- I prefer beets.- The price of one $50 \mathrm{~kg}$ is $25 \$$, the price of the second item is $32 \$$ for $45 \mathrm{~kg}$.- Why is it too expensive-It rained a lot this year. So, weeding, declining and spraying cost a pretty penny.- Okay. I believe you. Can I take $49 \mathrm{~kg}$ of the first kind and 20 of the second one-Sure!- What's about chicken forage?- I offer you ta find corn.- How much does it cost?-10\$ per 30 kg.-I'm buying it.- That's all-Yes, thanks for your help. Have a good day!-You too!» or «-Hello, welcome to our agricultural company. What would you like to know ?-Hi, I'm wondering what crops do your agronomists grow? Thanks for your question. We are focused on cultivation of peaches, apricots and plums- What are your favorite items? Actually I prefer figs most of all.-OK, our partners from the southern Ukrainian region are engaged into such figs cultivation. Wait a minute while we 'Il contact them .-I agree and I'll wait .-Mm, unfortunately, due to the heavy rain the yield suffered a little and they are waiting for the next year for new fig planting-I see. I'll take apricots then.-Nice choice but what are your favorite fruits and vegetables in general?- I like tomatoes, carrots, apple and bananas.-Tomatoes and bananas cost 20 UAH each, apples and carrots cost 15 UAH each. Buy fresh fruit and vegetables for a good price! Ok, I will take 1 kilogram of tomatoes and 1 kilogram of apples as well as above named apricots!- Fine, the opposite offers some industrial crop products, such as hemp shoes, shirts, and hats.-Ok, I will observe them another time. Goodbye.-Thank you for your purchases, see you next time» or «-Welcome to the farmer's market. Can I help you.Yes, please. I want some fresh vegetables.-These tomatoes are perfect-Oh good. I like 
some tomatoes-A three pound bag costi 70 UAH.-I'll take a bag, thanks-Okay. Anything else today-No, I will cook borsht for dinner, so I need $1 \mathrm{~kg}$ of red beet, as well as potato, onion, pepper, cucumber, dill. I think that growing is difficult. You dealt with watering as well as harvesting, transporting to the storehouse, crop rotation planning. -Yes, I am glad that understand me. It will cost 100 UAH for whole order. -Bye-Bye. Come again!» as well as «-Good afternoon -Good afternoon -Do you have ripe tomatoes?Yes, of course, how many kg- How many kilograms do you need?- It will 10 UAH per kilogram Well, give me these tomatoes-So you will like these tomatoes of the best quality».

The update the fourth version of the dialogues to represent plant products would be represented as the following replicas: «- Hi, let as specify the representatives of different plant products items. -Well, I agree but what are they in general? What do you exactly mean?-I mean such fruit as pear, plum, apple, peach, melon etc. and such vegetables as potato, cabbage, tomato, cucumber, red beet etc. -Well, I think that they are known to the majority offarmers to grow and common people to consume. I agree but do you know about the cereals? - Well, I know only wheat. Is it anything else? Yes, There are buckwheat, millet, rice, rye and oats. -Oh, are all of them grown in Ukraine?- Well almost all crops are in need and process of growing and consumption but meaning rice as the experimental crop.- I see, you are so clever.- But what about the berries? - Oh, do you know that the watermelon is considered to be a berry but not a fruit from the agronomist's point of view - Well, it's difficult to adopt such information but tell me please about the titles of real berries? - They are raspberry, blueberry, strawberry, cherry etc. But why is strawberry called in such way because I know that straw is the died grain crop stem?-well, I do not know exactly but may be it's word game-the false translator's friend or may be it means that it's worth to save a proper form of berries without damages while laying straw between the rows.- Oh, nice version but let us specify it according to scientific agronomists' manuals.- Yes we'll be able to take it into consideration but we need to carry philological work out too.-I agree but what do you know about the representatives of fodder and industrial plants?-They are rape, sunflower, maize, sugar beet, clover etc to be mostly used for 
cattle forage or the raw material for the further processing. Well, it's interesting. But may the word nut be used only as plant product title? -It may be used as a false translator's friend too meaning detail to be screwed by technical worker. -I see but can you tell me about main representatives of mushrooms, herbs and nuts themselves?Oh, too many questions I'm tired. Leave me alone please.- I see, sorry to have troubled you. -Not at all, you are welcome but not today. We need to postpone further specification of plant products titles-I agree, bye.-See you later.

Another plot of discussing plant products in general was focused within the fifth dialogue version as«-Hi, what is your thought about visiting farm which grows different agricultural products- Well, I am glad that I have already gained some valuable experience and can even give advice to those who come to our farm to learn the same technolo gies. I advise on the processes of growing lettuce, greenery, melons, celery, cherries, sweet cherries, and peaches. This is my profile -I see but must modern agronomist know different machinery to plant, to cultivate or to harvest plant products?- $\quad I \quad$ am convinced that automation and IT technologies will be necessary for control and optimization in the use of mobile equ ipment tractors, sprayers.

But an agronomist'ss assistant in the field of gadgets can be mobile laboratory to identify certain plant diseases in current regime as well as we in need to obtain weather forecast station because of unpredictable weather conditions.-But is the machinery main in the work of agronomist?.The most important thing will still be the direct presence of a specialist in the field, his observation, experience.-I see but what are your breaks and relax while plant products

growing?-

The profile of our farm does not allow us to relax all year round. Even in winter there are permanent works, for example, in greenhouses. The last time I managed to go home was before the beginning of June. I can visit relatives several times a year, cutting out 4-5 days. However, agronomists we go for Christmas for a couple of weeks.-oh, It's difficult schedule and time-table. 
How long does agronomist's working day last?

Friends and family know that in high season we work almost during seventeen hours a day. Those who are going to become an agronomist, I advise you to prepare yourself for hard work. If you have some doubts about your love for this profession, do not take it. - Do you regret about your choice? I didnot regret mychoicefor a second! Because the future of Ukraine is $100 \%$ agricultural. An IT specialist sitting in an office or a salesman does not feed the country with tomatoes, bread and potatoes. As we do, we are agronomists».

It was also an interesting aspect of dealing plant products with the agronomy in general in such sixth dialogue version as «-Hi, let us discuss agronomy as the science to find the best ways to plant and to cultivate different plant products.-I agree, Agronomy is the science whose objective is to improve the quality of the processes of the production and the transformation of agricultural and food products.-what does agronomy study?- Based on scientific and technological principles, it studies the physical, chemical, biological, economic and social factors that influence or affect the production process.-Oh, you know a lot. But what is its object of investigation? - Its object of study is the complex phenomenon or social process of the agroecosystem, understood this as the specific model of the intervention of the human being in nature, for purposes of production of food and raw material. And do you know that crop growing is an important branch of agriculture as well as animal husbandry but with the larger amount of agronomists to be engaged into it.- They are techniques to produce plant products using the resources provided by nature»

As it was earlier mentioned this discussin plant products attracted much biotech students' interest other versions of discussing plant products selling situation may be represented in such seventh version samples as-« Hi, let s discuss interesting facts about plant products economy.-I agree. Let's start.-Do you know that Ukraine is one of the three world leaders in barley production, is one of the largest producers of sugar beets, and is one of the seven world leaders in sugar production?-I think so.-What 
mathematic calculations are dealing with the agricultural products and their production? -Oh, there are a lot of them to be mentioned. Please announce the first fact.-Well, please know that to accommodate the entire crop of corn grown in Ukraine in one year, you will need 43 Olympic stadiums, or a train with a length of $3700 \mathrm{~km}$.Well, it's interesting but what is the second fact?-You see that Ukraine produces more sunflower oil than the whole world - olive oil: 1852 swimming pools can be filled with domestic sunflower oil. What do you know about nuts?- I know that Half a billion Kyiv cakes can be baked from Ukrainian nuts and every fifth Ukrainian works in the agricultural sector. Oh, you are so clever. May you represent the last mathemetic facts being related to plant products and their producers? - I know that Ukrainian farmers feed 140 million people on the planet and some decades ago the area of Ukrainian chernozem reserves is equal to the area of Great Britain-Oh, wonderful answers.I have never heard better explanation.-Tanks for your attention.-See you later.-Bye» or «Hello -Hello, how can I help you?-I want some potato, do you have it? -Yes, we have. Our potato is the tastiest and the freshest in the market. -How did you grow it? -First of all, we weeded topsoil then sowed tubers and watered. After some week we sprayed against pests and diseases and regularly fertilized. -Nice, I think your potato is great. How much will five kg cost?-Fifty hryvnas. -Also, what fruits you can recommend me?We have many types of fruits: pear, cherry, plum, apple, peach, melon, watermelon, grapes, banana and orange. What do you want?-I'd like to have two $\mathrm{kg}$ of oranges. -It cost two hundred hryvnas.-Oh, it's very expensive for me. Do you have radish and how much it costs? -We have Ukrainian radish, which cost one hundred hryvnas, and European radish, which cost fifty UAH. -I want one kg of Ukrainian radish. -OK, you should pay one hundred fifty UAH.-Here you are.-Thank you».

Thus the discussing plant products gave basic seven version students' dialogues.

We can not avoid topic «Soil» because land is the the main treasure of society to represent adequate dialogues too on the basis of some theoretical data to connect the sphere of land management with agronomic interst several versions too. 
The additional material dealing with land for agronomists was transfored from the electronic course for future land managers[412] mentioning working the next abstacts out: «Land cadastre describes the plot from the material point of viewr Land cadastre deals with land bonitet inventory. It is the list of land properties and its quality evaluation for cost definition like soils boning. Cadastral map may be periodically changed due to repeated cadastral photoplan surveying data to conclude general land management project. -Thus, every land manager must know about 9 categories of land purpose being described in Article 19 of the Land Code: 1) farm use land; 2) the land of residential and public buildings; 3) the land of natural reserve and other nature conservation purposes; 4) land of sanitary purpose; 5) recreational resort use lands; 6) land of historical and cultural destination; 7) forest plants land; 8) the land of the water fund; 9) industrial use lands, transport use lands, communication; energetic lines use lands, defense use lands etc. -Also land cadastre pays attention on bad degradated land and arable land.

A land manager deals with environmental protection in general and with soil and land protection. Soil is the surface layer of the earth on which land plants grow. Its protection involves soil rational use, soil stabilization, land melioration, land recultivation through fertilization, irrigation and crop rotation apartly.

A land manager must know about such kinds of soils as clay, sandy, peat, silt, soil and rock soils, saline soils, highly organic land( black soil), loam containing sand, clay and organic matter etc as well as methods of soil conservation like rotation of cover crops or green manure with other crops, planting windbreaks to stop topsoil loss from wind, perimeter runoff control to prevent erosion as well as grassways or plowing rows perpendicular to the hills.

A land manager must detect the samples of bad unproductive lands and must be able to detect and to map marshland, brook or lake basin, estuary, preserve, gardens and fields, grasslands and meadows vineyards for every separated locality area. He must know about drio irrigation system ti prevent overwatering during rain or high wind.[412]) 
The adopted, retold dialogue was be adapted and mentioning in the first version dialogue being dedicated to soil problems dialogue: «- Good afternoon!-Good afternoon!- Welcome to our store! How can I help you?- I have a question. Why is good soil important?-Good soil is the key to a good harvest, the better the soil, the greater the harvest. The parent material is also very important.- Thanks! Can you please give me 3 kilograms a soil for citrus.- 3 kilograms cost 30 UAH. Anything else today?- No. I will planted tangerine, so I needs 1 kilograms of humus as well as loam, sand and clay.- Tangerine need good parent material and beautiful aeration. It will cost 95 UAH per whole order.- Thank you very much but can you tell me about the main types of soil?-There are such kinds of soils as clay, sandy, peat, silt, soil and rock soils, saline soils, highly organic land ( black soil), loam containing sand, clay and organic matter etc.-You are so clever but what are the methods of soil conservation? -There are some methods of soil conservation like rotation of cover crops or green manure with other crops, planting windbreaks to stop topsoil loss from wind, perimeter runoff control to prevent erosion as well as grassways or plowing rows perpendicular to the hills. At school we were told about the importance of soil conservation. For a good harvest, people need to know what to plant. The land manager must identify suitable planting areas. Soil is the surface layer of the earth on which land plants grow. Its protection involves soil rational use, soil stabilization, and land melioration, land recultivation through fertilization, irrigation and crop rotation apartly. - But must every biotech student know about soil?-Yes, he must be able to distinguish such kinds of soils as clay, sandy, peat, silt as well as irrigation system to prevent overwatering during rain or high wind». Other samples of students' dialogues being devoted to soil are in following variants: «Hi, Mike. May you borrow me textbook «Soil»?-No, because I need it myself. Can I help you more ?- Yes, can you tell kinds of soil in general and in native region?- They are clay, sandy, peat, silt, soil and rock soils.What are your favorite words according to topic«Soils»? - I liked such terms as «clay» and «soil recultivation». - OK. And what is adequate conversational situation applying these terms?- Once upon a time a land manager worked with clay. For this he needed to study the land code. Only then could he work with clay, peat, estuaries. 
The customer liked his work and he decided to conclude a vineyard map with him. And what happened further? Well, next time my dad decided to write an article about soils. He got acquainted with different types of soils. The surface layer of the earth consists of clay, sandy, black soil, loam, saline and green manure. He also wrote about the rational use of soil and soil stabilization to reduce the amount of bad degradated land. Thus, he brought people together to protect the soil» or «Hello, do you know that soil is the upper layer of the earth?-Yes, but what kind of soil is there in your country?There are such kinds of soil as forest steppe, black soil as well as silt, sand, loam, etc.You are clever. Well done.-Have you ever planted any crop into soil? Yes, I have an practical experience to sow wheat, barley, maize and buckwheat. -And have you ever observed real soil samples? Yes, a little bit and have already know that the sample from the north field had a lot of sandy soil in it and poorly suited for growing any crops despite this type of soil quickly warms up, aerates well, is easily processed, but at the same time it cools quickly, dries up soon, and weakly retains mineral substances in the root zone.-Thanks for your answers.-Not at all. You are welcome»

The second version of the dialogue about the soil was involved into the following phrases: «-Welcome to the farmer's market. Can I help you.-Yes, please. I want some good soil.-I have a question "Why is good soil important?-Healthy soil is the background of productive, sustainable agriculture-Thanks. I will take two bags.-A two bags cost 70 hryvnia. Anything else today?-No. I will plant flowers, so I need $1 \mathrm{~kg}$ of humus as well as clay, loam, and sand.-Flowers need good soil parent material and beautiful aeration.-Thanks for the advice.-it will cost 200 UAH for whole order.-Bye!Bye. Come again!» or dialogue like «-Hello, agronomist, I want to ask you about recent 2021 yield.- Hi, this year was actually dry and central Ukraine was hit by hot weather and more adequate weather conditions are more desired for crops to withstand. -But what type of soil is more suitable for maize?-The best soils are nitrogen rich chernozems, loams and sandy soils. Therefore drought leads to yield decreasing and there must be some steps to improve soil like improvement of soil structure, creation of optimal conditions for the growth and soil aeration» . 
The third version dialogue about the soil may be introduced in such dialogue as «Good afternoon!-.Good afternoon! - Sir, can you tell me how to properly care for the soil?- And what exactly are you interested in, do you have any problems?- Yes, I am a young agronomist, but I have a problem with the soil. It is too dense. That is why I want to address you as an experienced agronomist.- Well, I understand well, it's a very long process.- I still have a lot of time to pass the job- In wet weather, yields decrease with any increase in compaction. Soil compaction in wet years reduces aeration, increasing denitrification. The risk of root diseases may also increase. All of these factors add stressto the crop and ultimately lead to crop loss. so, and what's next.- When soil compaction increases above the optimum, yields begin to decrease. In dry years, soil compaction can lead to plant growth retardation. Without timely rains and timely fertilizers, yields will decrease.- Okay, thank you very much!- Please, goodbye!».

The fourth kind of soil dialoguemay be noted as the next one: «-Hello, can I ask you some questions?-Hi, of course.-First of all, what type of soil have your fields?Our fields have only loam. For our opinion it's one of the best types of soil because loam has good aeration and holds water well. -What is about sand or clay? -Sand is a material made of small pieces of rock and mineral. Sand particles are too loose to hold enough water. Clay is very dense, so has bad aeration. -Why is good soil important? Good soil is important because all start in it. Soil like house for plants. Soil must have enough amount of water, air and nutrients. A soil's parent material determines what nutrients are in it. You can improve the nutrients by adding humus. -How do you measure soil acidity?-We have special device, which measure acidity.-What else are important issues with the soil?-I want to say about soil texture. It's the size of particles in a soil. It really very important, so be careful.-Ok, thank you a lot.-No problem!»

The fifth version of soil dialogue deals with the following phrases: «Hi. Can I help you with anything?-Yes. I need some soil.-What kind of soil is it in your region?Sand, I need soil for tomatoes, carrots and pumpkins.-Acidic soil is suitable for them, I advise you to take loam.-Thanks, I also need something to help the houseplants grow well.-You need a soil mixture of sand and humus. One bag of this mixture costs 100 
UAH.-Give me two bagsplease-Ok, anything else?-No, thank you.-Okay, thank you for buying. Goodbye-Goodbye» or Greetings, Constantine. And hello to you, Ivan. Konstantin, I wanted to ask you about the soil on your territory? Okay, I'm listening to you.-I heard that you are engaged in grapes in large quantities and I would like to ask, what is the essence of the soil? There must be some kind of zest. -That's right, my soil is light, sandy, loose, and permeates heat easily. -For this, some additives are used, but for them something like that later.- Ok, thanks Constantine! Still wondering what kind of soil you have, for example, for blueberries and raspberries? Yes, blueberries need soil with an acidity of 4.0-5.0 ph, or peat bogs and soil with humus, but raspberries need dry soil, that is, loamy. -Thank you very much Konstantin. -Please always contact. -OK, good bye. -Have a nice day».

The sixth dialogue version about soil which attracted students' scientific interest and was archived within electronic courses Moodle platform is «Hi, let us discuss some interesting facts about land and soil. What is the first fact?-In terms of their total biomass, the earth (Earth's land) is almost 700 times larger than the ocean, although land accounts for less than 1/3 of the earth's surface. The most valuable arable land occupies only $11 \%$ of the world's land fund-Oh, it's really interesting but do you know any adequate mathematic calculations dealing with land and soil? -Due to soil erosion, the planet loses 3 million hectares of land, Ukraine has 650 types of soil, and 130 thousand worms are able to turn over 30 tons of land. - You really know a lot. But do you know anything about World Soil day?-Well, I know that every year on December 5, humanity celebrates the International Soil Day which was initiated by the Food and Agriculture Organization of the United Nations .-Excuse me but I've asked about World Soil Day but not about International Soil Day. -These determinations are the synonyms. -Oh, I see. But why must we save the soil?- The process of soil formation is very slow. In the middle latitudes of the temperate zone, a fertile layer of soil 0.5 - 2 centimeters thick is formed in about 100 years -A lot of thanks for your detailed explanation. See you later-Bye».

Thus there were six main versions of dialogue about the soil to be represented by future agronomists and biotech students during their first semester studying. 
Also it's worth to mention that above named soil discussion undoubtely may be added with discussing seeds as the objects to be put into soil to continue earth and people life.

Besides the represented dialogues about soil it was important to discuss the topic «Seeds» exampling some dialogues too.

The first version of seeds discussion may be represented as "-Hello.-Hello, David, long time no see.-Do you have anything to tell me?-Yes, I have one trouble.Which?-My plow, soil plowing mechanism, has been broken.-You should have been more accurate. Take it to a mechanical engineer. I also have another question.Which?- For growing tomatoes a good soil is loam with a high content of silt, right? Yes, it's true. And what is another question?-Good soil is important for high crop, right?-I suppose that you are right but each concrete crop need to be planted into adequate soil mostly suitable for it- And do agronomists study how to make the soil more productive?- They classify soil types and study them to determine if they contain vital substances for plant development--Can I help you with anything directly now?Yes I need some soil samples.-Ok it is for indoor or outdoor plant?-It's for outdoor plants.-What kind of plants is it for? It's for vegetables-I have some tomatoes I would like soil being the mostly adequate to this crop.-In that case you should use doom. It has good aeration and holds water well to -What kind of soil is therein your country? We have many different types of soil. Dark, rich soil is used for drawing crops loose sandy soil is found in the deserts, and day which is not very fertile can be found throughout the Ukraine -Ok I'II take it. Thanks for your help»

The second version of the seed dialogue is the next «Hello, welcome to our store. How can I help you?-Hi, I'd like to buy some seeds.-Which seeds is of interest to you?I'm interested in cucumber seeds.-We have the following varieties: «Asterix», «Cuckoo», "Crane», «Alliance», «Amarok» and «Accord».-Give me two packets. So how did you grow them?- Any disinfectant infusion should be prepared for seeds. We mainly use manganese of low concentration. Soak the seeds for 15-20 minutes, remove the seeds from the solution, rinse and allow to dry or leave to germinate. Seeds for seedlings can be planted in one wide container, and when it's time to grow tomatoes 
on the windowsill, just transplant the seedlings into large pots. Seeds should not be sown close to each other and deep. Try to leave a distance between the seeds of $2 \mathrm{~cm}$ and a depth of $1 \mathrm{~cm}$. When the seedlings appear two leaves will need to transplant the plants into separate containers. It is necessary to select capacity proceeding from the sizes of this or that grade. For example, for ordinary tomatoes you can take a pot with a capacity of at least 4 liters, short - 2 liters, and plant tomatoes planted in pots of at least 5 liters. For tomatoes, it is important to provide additional nutrition, as well as to organize watering every 15 days with a weak solution of manganese.-Oh, you have the technology of growing tomatoes, I think they taste the same as your technology, that is, perfect.-Bye.

Another third version to discuss seed need situation touches upon such replicas as «-Hi, you will like these tomatoes of the best quality. So how did you grow them?Any disinfectant infusion should be prepared for seeds. We mainly use manganese of low concentration. Soak the seeds for 15-20 minutes, remove the seeds from the solution, rinse and allow to dry or leave to germinate. Seeds for seedlings can be planted in one wide container, and when it's time to grow tomatoes on the windowsill, just transplant the seedlings into large pots. Seeds should not be sown close to each other and deep. Try to leave a distance between the seeds of $2 \mathrm{~cm}$ and a depth of $1 \mathrm{~cm}$. When the seedlings appear two leaves will need to transplant the plants into separate containers. It is necessary to select capacity proceeding from the sizes of this or that grade. For example, for ordinary tomatoes you can take a pot with a capacity of at least 4 liters, short - 2 liters, and ampelnye tomatoes planted in pots of at least 5 liters. For tomatoes, it is important to provide additional nutrition, as well as to organize watering every 15 days with a weak solution of manganese.-Oh, you have the technology of growing tomatoes, I think they taste the same as your technology, that is, perfect. Everything is well!» of «Asterix» and «Alliance», and what do you need seeds to grow?-Ok, maybe you need something else?-Yes, give me one more bag of «Dobrodar» watermelon seeds.-Ok, but for good growth of this variety of watermelon requires a lot of water, so 4 times a week water the rows.-Ok, thanks for the advice. Goodbye.-Good day» or «-Hello, I'd like to buy some seeds.-Hi, what seeds do you 
need?-I want cucumber seed, do you have it?-Yes, of course. I recommend these seeds, which is titled as «Amur». Many farmers like this because from them grow big, tasty, and green cucumbers.-Great, but how do farmers plant seeds?-Sowing method is very interesting. Use a pen or similar shaped object to prepare holes $0.5 \mathrm{~cm}$ deep, $2 \mathrm{~cm}$ apart Drop one seed per hole. Cover with soil. Water.-What do need seeds to grow?Seeds need enough amount of water, air, nutrients. -Thanks, I understand.

The fourth veriion of dialogue concerning seeds may be introduced in the following way: Hi, How long will your seeds grow?-Days to maturity: 25. But first seedlings will after 3-5 days. -Cool, how much should I pay for 1 packet of seeds?-Fifty UAH.-OK, thank you, here you are. What varieties are you interested in?-Seed of wheat and corn will be required.-Sorry but in us there is no chance of this variety of seeds.But, to me need tomorrow it is a seed. For tomorrow rain is forecast-Fine. I will try buy this variety of seeds tomorrow. l'll dial tomorrow at 8 o'clock» .

The fifth type of the dialogue to discuss seed is the next one: «Good afternoon!Good afternoon!- Welcome to our store! How can I help you?- Yes, I collected cucumber seeds and want to know what do you need seeds to grow?- Sufficient moisture, sunlight, heat and good aeration are required for seed germination.Thanks!- Maybe you want to germinate some more seeds? We have a wide range! Maybe you are interested in watermelon seeds?-Yes, I'm interested, give me one package, please.-1 package costs 10 UAH.-Thank you, have a nice day!- You too! Goodbye!»

The sixth kind of seed conversation is the next:«Hi, there, welcome to our Fruit Farm.How can we help you? hello, I'd like to take a consultation about the proper way of watermelon growing. What do seeds need to grow? Well, listen to some useful information. Before soaking you need to warm the seed up. This can be done not at moderate temperature. You must soak dried watermelon seeds in potassium humate solution. This procedure can increase yields up to 20-50 per cent, And when will the seeds be ready.-As soon as they have swollen and increased in size you should proceed to germination. I want some good seeds.-Great. What varieties are you interested in?I want some watermelon, the Super King. And some melon, the Royal Gold-I am sorry. 
I didn't catch that. -Super King watermelon and Royal Gold melon.-Get it.-I need two packets of each I have a question. How do farmers plant seeds?-Farmers often till the land by loosening the soil and mixing in fertilizers. Then, they sow seeds or plant seedlings.-Thanks for the advice.-Bye!-Bye. Come again!»

The seventh version of seed dialogue deals with the next replicas:«- Good afternoon-Good afternoon-Can I buy a kilo of the best seeds from you?-What kind of seed crop do you want?-I need sunflower seeds so I can grow them and make a lot of money on them. -Yes, I have the best sunflower seeds.-This is what i need as cool.-As much as you need. -Give me 100 pounds. It will be about 1 and a half bagsю-And how much does it cost?- 4000 UAH. How wonderful, I just have 4000 UAH with me, thank you, have a nice day.-You too, good bye»

The eighth version of the conversation to discuss something about the seeds from the agronomist's point of view is the next: «-Hello.-Hello, David, long time no see.-Do you have something to tell me?-Yes, I have one trouble.-Which?- My seeder as seed spreading mechanism has been broken.-Well, you should have been more accurate. Take this to a mechanic.-I also have two questions.-Which?-Cold-weather hybrid broccoli survives in temperatures down to $37 \mathrm{~F}$, did not it?-Yes, it does, it's true. And what is another question?-Seeds need light, water and soil to grow, do not they?-Yes, they do. That's also true. Well, broccoli is very helpful to keep fit and agronomists should spread their activity in the point of growing broccoli as well as cabbage, carrot, parsley, marrow and dill -Okay, then, can I go?-Yes, you can ».

The ninth version of the dialogues about seeds may be represented in such samples as «-Hello! Hello.CanI help you?L:-Yes,we can.I want to plant wheat, but I don't know what type of soil is best for this ...-Chernozems are considered to be the best soils for growing. Wheat can also grow well on podzolic, chestnut and sod soils.L:Oh thank you. And what fertilizers are best to fertilize the soil, nitrogen or phosphate?It all depends on the variety. Winter wheat prefers phosphorus fertilizers, and spring wheat-potassium.: -What can be the yield of wheat from 1 hectare, subject to all conditions.:-It all depends on weather conditions and compliance with seeding rates. The maximum yield can be 7.2 tons per hectares.-Okay, thank you.-You welcome!» 
Another version of discussing soil problem : «-Sir Adam, sir Adam! Can you help meOh, hi Jackson! What you need-Tell me, how much fertilizer to take on 3 hectares of soil-I think, $86 \mathrm{~kg}$ per one hectare will be sufficient. Will you present at processing?No, I'm going on a business trip. At the moment we have everything what you need-I think, not this time. Humus doesn't provide nutrients for the soil.-Fine. Will the plants do well in light loam-Yeah, I guess so.- I hope it all works out.-Everything will be all right.»

It's worth to say that discussing seeds became the object of scientific and communicative interest not only for the freshmen- future agronomists which point of view was above named but also for the second-year students- future biotechnologists in more detailed tenth versions in a following way: «-Hello.-Hello, David, long time no see.-Do you have something to tell me?-Yes, I have one trouble.-Which?-My seeder as seed spreading mechanism has been broken.-Well, you should have been more accurate. Take this to a mechanic.-I also have two questions.-Which?-Cold-weather hybrid broccoli survives in temperatures down to $37 \mathrm{~F}$, did not it?-Yes, it does, it's true. And what is another question?-Seeds need light, water and soil to grow, do not they?-Yes, they do. That's also true. Well, broccoli is very helpful to keep fit and agronomists should spread their activity in the point of growing broccoli as well as cabbage, carrot, parsley, marrow and dill -Okay, then, can I go?-Yes, you can ».

The eleventh version of the dialogue about seeds may be noted bellow: Oh, Tony, hello! I'm happy to see you. Tony, please come in. We haven't seen each other for so long. I've heard about your working and I consider your new seed is almost ready for marketing. - Hello, George. I'm happy to see you too. Oh, these rumors are spreading too fast. Yes, it is. After the animal performance assessments it will be ready to go.Wonderful. Tell me about it in the first person. I want to know the best way to advertize it.- You always narrow everything down to profit you will achieve and money. I'm not interested in it. I just do my study and that's all I keen on.- Ok, come on, Tony. You have to make for a living and I 'll make your ideas come true to transfer brilliant projects into money, is it bad? I help you to make money from it for you equipment and apportunities you'll have in future. So, tell me about your project and don't force me 
being mad at you.- All right, well, the main benefit is that it's extremely droughtresistant.- There we go, that's great. We will do adequate selling it to farmers in dry regions.- Good point. I'll target areas where rainfalls are unpredictable.- Yes, what else?- We should emphasize the dependability at our seed. Tests should that the yields produced during rainy seasons and those produced during droughts varied very little and they're letter for the environment than conventional seeds. - That's your job. How you will do it?- With fener crops failing during drought seasons there'll be greater yields. That means less land will be used per season. - Excellent, Tony. - O my God, George. I'm late. My break is over. We can meet tomorrow and discuss this issue in more detail.- Oh, ok. No problems. See you tomorrow. B: Good bye!»

The twelfth type of seed dialogue is in the following sentences: «- Carol, please come in. I understand your new seed is almost ready for marketing. - It is. After the animal performance assessments, it will be ready to go. - Wonderful. Tell me all about it. I want to know the best way to advertise it.- Well. The main benefit is that it's extremely drought-resistant.-Okay. So well do well selling it to farmers in dry regions. - Yes. We'll target areas where rainfalls are unpredictable. - Okay. What's else?- We should emphasize the dependability of our seed. Tests showed that the yields produced during rainy seasons and those produced during droughts varied very little and they re better for the environment than conventional seeds.- How?- With fewer crops falling during drought seasons, there'll be greater yields. That means less land will be used per season. - I had a great idea. I will offer this seed to my brother, he has a lot of land and may want to try new seeds.- Yes, that would be great. And then he could advise these seeds to his fellow farmers.- I am sure that soon these seeds will enter the world market and will bring good harvests.- I really hope so and thank you for your help»

The thirteenth version of seed dialogue deals with the following expressions: «Carol, please come in. I understand your new seed is almost ready for marketing. - It is. After the animal performance assessments, it will be ready to go. - Wonderful. Tell me all about it. I want to know the best way to advertise it.- Well. The main benefit is that it's extremely drought-resistant.- Okay. So well do well selling it to farmers in dry regions. - Yes. We'll target areas where rainfalls are unpredictable. - Okay. What's 
else? - We should emphasize the dependability of our seed. Tests showed that the yields produced during rainy seasons and those produced during droughts varied very little and they're better for the environment than conventional seeds.- How?- With fewer crops falling during drought seasons, there'll be greater yields. That means less land will be used per season.- I had a great idea. I will offer this seed to my brother, he has a lot of land and may want to try new seeds.- Yes, that would be great. And then he could advise these seeds to his fellow farmers.- I am sure that soon these seeds will enter the world market and will bring good harvests. I really hope so and thank you for your help.-Excellent, Carol».

Thus the topic soil became the most productive and attracted the most of student's interest.

And now it's a turn to discuss plant growth as the last one to be represented in this article exampling.

The first version of dialogue to discussplant growth may be represented within the next dialogue: «Hi-Hi-Taras, you planted sunflower for the first time this year, didn't you?-I did, I was worried at first but it seems okay now.-Worried? Why?-it was growing so slowly. But it just took a while for the buds to flower--Oh so they'were doing well-yeah. They are we expect to harvest them next week-That's great. How much do you expect to harvest? Well we planted 6 acres. So probably for few acres or so-Haw do plants change as they grow? While their grow plants get bigger and more resistible to damages. Their roots grow longer in order to draw more water and to support the plant. Leaves increase in size and number and most plants produce flowers-Ok, thanks. Goodbye-Goodbye

The second version of seed dialogue is the following sample:: $« H i$, it is in need to provide at least 10 inches between rows of quinoa to give the roots plenty of space, is not it?-Yes, It is ,it' true and I support such version. -What is in need for barley growth?-Well, barley like every another crop, needs watering, weeding and fertilizing-Ok. Thanks for the advice And what is another question? I'd like to specify root functions. What are they? They are absorption of water and minerals and conduction of these to the stem-I see, thanks for answer. Do you want to know anything 
else? - I'm in doubt with need to waiting two weeks to plant after using some herbicides.-Is this true?-Yes, it is and I have practical experience with fertilizing and herbicide application. But can we avoid pesticides at all? May the pollute environment.- we must be careful but can not refuse while cultivation large fields area. Herbicides are used to avoid weeds which may made seedlings weak.-Is plant growth studying in need for Ukrainian agronomist?- I see tat it's true. Ukraine grows 7 times grain than coffee worldwide. Ukraine is one of the three world leaders in barley production, is one of the largest producers of sugar beets.-How do plants change as they grow? -Their roots grow longer ir order to draw more water and to support the plant. Leaves increase in size and number and most plants produce flowers-Thanks for your answers» .

The third version of plant growth dialogue is the next one: «-Hello-Hello. What did you plant this year?-So I planted corn, sunflower, wheat and I tried to plant quinoa.-What is quinoa?-Qquinoa is plant seeds which are used as spices in various dishes.-Oh, it is interesting. Is it difficult to grow quinoa?-No, it is not so difficult, but I don't know this plant well so I worry about that.-worried? Why?-I'm worried because of watering of quinoa and other plants. there was very little rainfall this year. -Well, it is the most popular problem in agronomy. -So how much do you expect to harvest this year?-I expect to harvest 6 tons per hectare of wheat, 8 tons per hectare of corn, 3,5 tons per hectare of sunflower. But I don`t know how much quinoa I will harvest.-OK, it was interesting to learn about quinoa. - But have you any agronomist's practical problem?- Last year my corn crops grew poorly but I don't know why.- May the problem be in the land on which it grows?- No, I do not think so, I have good soil.Then maybe the cause is in pesticides?-Obviously not, I have imported pesticides-I don't even know what to say, I can only advise good corn seeds. -And you're right I did not take care of the seeds that I plant.- In this case I can give you the phone number of my friend who sells various seeds. -Now I will find his business card.--Thank you for helping me a lot, I'm your debtor». 
The fourth version of plant growth dialogue is the next one: «What will we grow at this year?-I think, sunflower is cool decision.-What advantages of growing sunflowers? -First of all, sunflower grows quickly and has big harvest.-I can't disagree with you. But what about growing process?-Sunflowers grow very fast. First seedlings will be after 1-2 weeks. After 1 month sunflowers will have strong stalks and big, green leaves. Also, sunflowers like water, so we should regular water them and add in soil enough humus and fertilizers.-What function does each part of a plant?-Oh, it's great question. Roots up water and nutrients for upper part of plant. Leaves do photosynthesis. Stem holds the whole plant. -Is sunflower a popular plant?-Yes, of course. Sunflower oil is very popular and important product.-How much do you expect to harvest from this field.-We expect 20 tons from 10 hectares of field» or «-Welcome to the farmer's market. Can I help you.-Yes, please. I want to plant flowers.- What varieties are you interested in?-I want some roses. Do they grow fast?-No, roses grow slowly.-How do plants change?-The stem grows and then in formed bud.-Thanks. I need two packets of roses seeds.-It will cost 100UAH for whole order.-Thanks! Now I know more about plants» as well as $\mathrm{Hi}$, I have recently planted quinoa as an ornamental plant.-Cool, I also like her look, and you know what function does each part a plant serve?-Yes, roots-nutrition, leaves-photosynthesis, stem-support and branch. - And did you know that only few plants obtain as much protein as quinoa, and it can grow in many environments. -No, I did not, it's very interesting. And how it should be grown?-Sow the seeds where the plant will get plenty of sunlight, at a distance of 10 inches, so that the roots grow.-I understand, thanks for the info. Apparently also sowing quinoa. Looking forward to next time.-I will look forward to it too»

The fifth plant growth discussion is in the following sample :«-Hi, Ann, you planted broccoli for the first time, did not you?-Yes, I did. I worried about my new experience but I realized that it was not so difficult.-That case is interesting. Can you tell me about broccoli growth in details? -With pleasure This cool crop is rich in vitamins and minerals and is a proper source of vitamin A, folic acid, iron and fiber. Broccoli grows on areas with plenty of sun and well-drained fertile soil. Avoid sandy 
soil if it is possible- How do broccoli change as they grow? Broccoli seeds typically germinate within10 - 14 days period. During the first year the broccoli stalk grows on70-80 cm in height. Later they'll obtain comparatively thick stem. And what about the place where to grow? These seeds may germinated either indoors or outdoors because they are very adaptive. And what harvest do you expect? Well, it was experimental planting only in few balcony pots and can not even predict the amount of yield.-Thank you so much, we wish you the best harvest.-Thanks. bye».

The sixth plant growth discussion is in the following sample: "Good afternoon!.Good afternoon! -. Oleg, how do you grow plants, are they all well developed?-In general everything seems good, but there are some problems.- What exactly are your problems?- Buds in the orchad fall off. Oh, so these are serious problems for you. Yes, I didn't even think it was a big deal-I will help you in solving this problem. I'll be grateful.- Plants live on rocks and trees. They need air and a tropical climate for normal life and abundant flowering. Failure to comply with certain conditions of maintenance and cultivation - the main cause of aging of tropical flowers. As a result of violation of the microclimate in the room the plant sheds buds and flowers, leaf blades wither, turn yellow and fall off, the roots dry out. There are a number of factors that directly affect the growth, development and flowering of orchids. -Wow, does that mean you need to make their living conditions normal?-Yes, and then you will succeedOkay, thank you. Contact us in need».

The seventh plant growth discussion is in the following sample: «Good afternoon!-- Good afternoon!- I need fertilizer that will improve the growth of my tangerine tree.- To begin, you need to read the growth chart of the tangerine tree. Here hold.- Thanks! Now I know why the leaves of my plant turn yellow.- I can advise you here is this fertilizer.- How much does it cost?- 80 UAH per a jar.- Give one please.Hold on! Maybe you need something to improve photosynthesis, root growth, flowering plants?- No, thank you! - Okay, I look forward to our next meeting!- So I do, goodbye! - Goodbye»

The eighth plant growth discussion is in the next version: «- Hi aunt Sara! What are you doing-Hi, darling. I plant new seeds that I received as a gift. It's a aster 
Sow White-Can you tell little bit about them-Yes, of course, Megan. The petals of this plant are long and curved. The length of the aster stem reaches 70 centimeters and flowers white and double. Their diameter is about 12 centimeters. - It's so interesting! Tell me more!-Okay, my body-body! Aster prefer to grow in sunny areas and fertile non-acidic soil. They don `t require a lot of effort to grow. They good for beginners. Can I try to plant them with you-Of course, Megan. Let's go!»

Thus there were eight different attempts to discuss plant growth.

The parallel activity to dialogue conclusion dealt with the writing own opinion on the clever phrases by famous person concerning agronomist's activity to be in five portions blocks within inspirational gardening quotes and sayings([419]) or inspiriting gardening quotes to encourage plant growing ([418])

The first block dealt with several statements

The first statement «To plant a garden is to believe in tomorrow» by Audrey Hepburn may be understood that people believe in future because can not see the results at once. It may be destiny of agronomist who takes care of another next generation beauty and food, is sure of land fertility and no ecological damages and the second one «Gardening is a work of a lifetime: you never finish» by Oscar de la Renta prove the difficulty and nobility of agronomist's work as well everlasting inner development, improvement and studying being in similar meaning to Chinese proverb «The best time to plant a tree was twenty years ago. The second best time is now» as well as to the statement "Don't judge each day by the harvest you reap, but by the seeds that you plant» by Robert Louis Stevenson.

The majority of students supported the thought «To forget how to dig the earth and tend the soil is to forget ourselves» by Mahatma Gandhi mentioning linkage of everlasting land cultivation. Without this activity the human life may be interrupted. This statement may be regarded as the continuation of the phrase «When the world wearies and society fails to satisfy, there is always the garden» by Minnie Aumonier too.

Despite of the difficult physical labor communication with nature as a rule bring esthetic pleasure and sometimes agronomist may become the artist proving the 
statement «My garden is my most beautiful masterpiece» by Claude Monet or «In all things of nature there is something of the marvelous» by Aristotle.Agronomist may be called even an actor or singe basing upon the proverb "The garden is a love song, a duet between a human being and Mother» as well as "All gardening is landscape painting» by William Kent or « To create a garden is to search for a better world. In our effort to improve on nature, we are guided by a vision of paradise. Whether the result is a horticultural masterpiece or only a modest vegetable patch, it is based on the expectation of a glorious future. This hope for the future is at the heart of all gardening» by Marina Schinz as well as «Watching something grow is good for morale. It helps us believe in life» by Myron Kaufmann.

The second block of phrases like "Gardening is cheaper than therapy - and you get tomatoes» by Anonymous or «The healing of the land and the purification of the human spirit is the same process» by Masanobu Fukuoka as well as «Gardening is the greatest tonic and therapy a human being can have. Even if you have only a tiny piece of earth, you can create something beautiful, which we all have a great need for. If we begin by respecting plants, it's inevitable we'll respect people» by Audrey Hepburn or «Flowers are restful to look at. They have neither emotions nor conflicts» by Sigmund Freud were announced by students as a thing being related to the therapeutic pleasant influence on human health and prove the statement that the agronomists who spend a lot of time outdoors are considered to be the healthiest people.

The last block of phrases include philosophical cognitive activity in finding rational background -advices for general agronomist's life within such statements as «No single sort of garden suits everyone. Shut your eyes and dream of the garden you'd most love then open your eyes and start planting. Loved gardens flourish, boring ones are hard work» by Jackie French or "If you've never experienced the joy of accomplishing more than you can imagine, plant a garden» by Robert Brault or noting Greek proverb «A society grows great when old men plant trees whose shade they know they shall never sit in» as well as «You are also far less likely to waste food when you have nurtured it from a seed into a plant»by Darina Allen or noting Chinese proverb 
"Life begins the day you start a garden» as well as" Gardening adds years to your life, and life to your years» by unknown writer as well as Greek proverb «A society grows great when old men plant trees whose shade they know they shall never sit in. ", "If you wish to make anything grow, you must understand it, and understand it in a very real sense. 'Green fingers' are a fact, and a mystery only to the unpracticed. But green fingers are the extensions of a verdant heart. » by Russell Page «Everything that slows us down and forces patience, everything that sets us back into the slow circles of nature, is a help. Gardening is an instrument of grace.” May Sarton, «The single greatest lesson the garden teaches is that our relationship to the planet need not bezero-sum, and that as long as the sun still shines and people still can plan and plant, think and do, we can, if we bother to try, find ways to provide for ourselves without diminishing the world. » by Michael Pollan, «Gardens are not made by singing 'Oh, how beautiful,' and sitting in the shade. " „Trees and plants always look like the people they live with, somehow.. » byZora Neale Hurston, «God Almighty first planted a garden. And indeed, it is the purest of human pleasures. » by Francis Bacon, «A person cannot love a plant after he has pruned it, then he has either done a poor job or is devoid of emotion. » byLiberty Hyde Bailey, " love spring anywhere, but if I could choose I would always greet it in a garden. Ruth Stout, «The garden suggests there might be a place where we can meet nature halfway. » byMichael Pollan, «I like gardening - it's a place where I find myself when I need to lose myself. » by Alice Sebold, «It is only the farmer who faithfully plants seeds in the Spring, who reaps a harvest in the Autumn. » by B.C. Forbes, «There are no gardening mistakes, only experiments. 》by Janet Kilburn Phillips, «But always, to her, red and green cabbages were to be jade and burgundy, chrysoprase and prophyry. Life has no weapons against a woman like that.» by Edna Ferber,«Gardening simply does not allow one to be mentally old, because too many hopes and dreams are yet to be realized. " by Allan Armitage, «There are two spiritual dangers in not owning a farm. One is the danger of supposing that breakfast comes from the grocery, and the other that heat comes from the furnace. » by Aldo Leopold,«A garden always has a point» by Elizabeth Hoyt, The Raven 
Prince, «The greatest fine art of the future will be the making of a comfortable living from a small piece of land. » by Abraham Lincoln, Chinese proverb «All gardeners know better than other gardeners. ", «When the world wearies and society fails to satisfy, there is always the garden. » by Minnie Aumonier, "How fair is a garden amid the trials and passions of existence. By Benjamin Disraeli.

According to the students' opinion the fourth block of expressions deals the expression of time period attitude to the agronomists' actions in such expressions as «Essential advice for the gardener: grow peas of mind, lettuce be thankful, squash selfishness, turnip to help thy neighbor, and always make thyme for loved ones. " by unknown author "The love of gardening is a seed once sown that never dies» by Gertrude Jekyll or «Plan a garden for the future, but expect it to evolve and need changing, despite your well laid-out plans. Such is the temperament of Mother Nature» by Meredith Kirton as well as mentioning the phrase «There are no happier folks than plant lovers and none more generous than those who garden» by Ernest Wilson or Chinese proverb "All the flowers of all the tomorrows are in the seeds of today» as well as «Remember that children, marriages, and flower gardens reflect the kind of care they get» by H. Jackson Brown Jr. or«If you have a garden and a library, you have everything you need» by Marcus Tullius Cicero, «A garden requires patient labor and attention. Plants do not grow merely to satisfy ambitions or to fulfill good intentions. They thrive because someone expended effort on them» by Liberty Hyde Bailey.

Besides, future agronomists and biotech students consider such expression as «Despite the gardener's best intentions, Nature will improvise» by Michael P. Garofalo, «The single greatest lesson the garden teaches is that our relationship to the planet need not be zero-sum, and that as long as the sun still shines and people still can plan and plant, think and do, we can, if we bother to try, find ways to provide for ourselves without diminishing the world» by Michael Pollan. be also mentioned among the advices to follow some life rules as well as the phrase «Giving up your ego is the shortest way to unification with nature» by Masanobu Fukuoka or «A garden is a grand teacher. It teaches patience and watchfulness; it teaches industry and thrift; 
above all it teaches entire trust» by Liberty Hyde Bailey or "The love of gardening is a seed once sown that never dies. » by Gertrude Jekyll

And now it's time to represent the list of the phrases about agronomy to become the source either of professional vocabulary or the items of cognitive and personal interst to be placed in scale od students' gradation:

1) «Gardens are a form of autobiography» by Sydney Eddison , «Remember that children, marriages, and flower gardens reflect the kind of care they get. " by $\mathrm{H}$. Jackson Brown, Jr.; «My garden is my most beautiful masterpiece» byClaude Monetб«I cultivate my garden, and my garden cultivates me. » byRobert Breault, «My garden is my favorite teacher» and Betsy Cañas Garmon «Weed it and reap». by Gardening Saying;

2) «Everything that slows us down and forces patience, everything that sets us back into the slow circles of nature, is a help. Gardening is an instrument of grace» by May Sarton or «Flowers always make people better, happier, and more helpful; they are sunshine, food and medicine for the soul » by Luther Burbank;

3) «Keep love in your heart. A life without it is like a sunless garden when the flowers are dead. " by Good Morning Quote or«Little things seem nothing, but they give peace, like those meadow flowers which individually seem odorless but all together perfume the air. . " by Georges Bernanos and «I know that if odour were visible, as colour is, I'd see the summer garden in rainbow clouds. » by Robert Bridges;

4) «Show me your garden and I shall tell you what you are» by Alfred Austin «The flower which is single need not envy the thorns that are numerous. " by Rabindranath Tagore or «A lawn is nature under totalitarian rule. » by Michael Pollan;

5)«Flowers are restful to look at. They have neither emotions nor conflicts» by Sigmund Freud and «And do notforget not that the earth delights to feel your bare feet and the winds long to play with your hair. » by Khalil Gibran or «Garden as though you will live forever. " by Thomas Moore;

6) «A man has made at least a start on discovering the meaning of human life when he plants shade trees under which he knows full well he will never sit» by D. Elton 
Trueblood and «A garden requires patient labor and attention. Plants do not grow merely to satisfy ambitions or to fulfill good intentions. They thrive because someone expended effort on them. " by Liberty Hyde Bailey or «Remember that children, marriages, and flower gardens reflect the kind of care they get. » by $\mathrm{H}$. Jackson Brown, Jr.;

7) «A weed is but an unloved flower. » by Ella Wheeler Wilcox or «What is a weed? A plant whose virtues have never been discovered» by Ralph Waldo Emerson and «Plant and your spouse plants with you; weed and you weed alone. " by Jean-Jacques Rousseau;

8) «I want it said of me by those who knew me best, that I always plucked a thistle and planted a flower where I thought a flower would grow» by Abraham Lincoln and «We must cultivate our own garden. When man was put in the garden of Eden he was put there so that he should work, which proves that man was not born to » by Voltaire or «Love is the flower of life, and blossoms unexpectedly and without law, and must be plucked where it is found, and enjoyed for the brief hour of its duration. " by D. H. Lawrence;

9) «A flower falls, even though we love it; and a weed grows, even though we do not love it. » by Dogen and «Weeds are flowers too, once you get to know them. » by A. A. Milne or «Won't you come into the garden? I would like my roses to see you» by Richard Brinsley Sheridan;

10)«My passion for gardening may strike some as selfish, or merely an act of resignation in the face of overwhelming problems that beset the world. It is neither. I have found that each garden is just what Voltaire proposed in Candide: a microcosm of a just and beautiful society » by Andrew Weil;

11) «Every time I imagine a garden in an architectural setting, it turns into a magical place. I think of gardens I have seen, that I believe I have seen, that I long to see, surrounded by simple walls, columns, arcades or the facades of buildings - sheltered places of great intimacy where I want to stay for a long time. » by Peter Zumthor;

12) «Sometimes, as is the case of peach and plum trees, which are often dwarfed, the plants are thrown into a flowering states, and then, as they flower freely year after 
year, they have little inclination to make vigorous growth. » by Robert Fortune or «The lesson I have thoroughly learnt, and wish to pass on to others, is to know the enduring happiness that the love of a garden gives» by Gertrude Jekyll;

13) «Isn't it enough to see that a garden is beautiful without having to believe that there are fairies at the bottom of it too? " by Douglas Adams or «The glory of gardening: hands in the dirt, head in the sun, heart with nature. To nurture a garden is to feed not just on the body, but the soul» by Alfred Austin and «It is a good idea to be alone in a garden at dawn or dark so that all its shy presences may haunt you and possess you in a reverie of suspended thought. » by James Douglas;

14)«There's something about taking a plow and breaking new ground. It gives you energy» by Ken Kesey or "It is a golden maxim to cultivate the garden for the nose, and the eyes will take care of themselves. " by Robert Louis Stevenson and) «I've always felt that having a garden is like having a good and loyal friend. " by C. Z. Guest;

15)«He plants trees to benefit another generation» by Caecilius Statius or «The love of gardening is a seed once sown that never dies. » by Gertrude Jekyll and «You can cut all the flowers but you cannot keep spring from coming. » by Pablo Neruda or «How deeply seated in the human heart is the liking for gardens and gardening. " by Alexander Smith;

16) "What a man needs in gardening is a cast-iron back, with a hinge in it. " by Charles Dudley Warner or «It is only the farmer who faithfully plants seeds in the Spring, who reaps a harvest in the Autumn. » by B. C. Forbes and «By plucking her petals, you do not gather the beauty of the flower» by Rabindranath Tagore;

17) «I think this is what hooks one to gardening: it is the closest one can come to being present at creation. » by Phyllis Theroux and «When the flower blooms, the bees come uninvited. » by Ramakrishna or «Fertilizer does no good in a heap, but a little spread around works miracles all over» by Richard Brinsley Sheridan;

18) «In search of my mother's garden, I found my own» by Alice Walker and «One marked feature of the people, both high and low, is a love for flowers. " by Robert 
Fortune or "I don't like formal gardens. I like wild nature. It's just the wilderness instinct in me, I guess. » by Walt Disney;

19)«A brier rose whose buds yield fragrant harvest for the honey bee. 》 by Letitia Elizabeth Landon and «I plant a lot of trees. I am a great believer in planting things for future generations. I loathe the now culture where you just live for today. " by Penelope Keith or «No occupation is so delightful to me as the culture of the earth, and no culture comparable to that of the garden. » by Thomas Jefferson; 20) «There are two seasonal diversions that can ease the bite of any winter. One is the January thaw. The other is the seed catalogues. » by Hal Borland and «A gardener's best tool is the knowledge from previous seasons. And it can be recorded in a $\$ 2$ notebook. » byAndy Tomolonis

21) «If you've never experienced the joy of accomplishing more than you can imagine, plant a garden.» by Robert Breault and «Creating your own urban farm is as simple as planting your flowerbeds with edibles. " byGreg Peterson and «In order to live off a garden, you practically have to live in it. " byFrank McKinney Hubbard or «Gardeners learn by trowel and error.» by Gardening Saying

22) «One of the most delightful things about a garden is the anticipation it provides. » byW.E. Johns, The Passing Show and «I grow plants for many reasons: to please my eye or to please my soul, to challenge the elements or to challenge my patience, for novelty or for nostalgia, but mostly for the joy in seeing them grow. » by David Hobson and «There is no gardening without humility. Nature is constantly sending even its oldest scholars to the bottom of the class for some egregious blunder. " by Alfred Austin and "If you have a garden and a library, you have everything you need» by Marcus Tullius Cicero;

23)A garden requires patient labor and attention. Plants do not grow merely to satisfy ambitions or to fulfill good intentions. They thrive because someone expended effort on them» by Liberty Hyde Bailey and «The roots of all goodness lie in the soil of appreciation for goodness» by Dalai Lama and «The glory of gardening: hands in the dirt, head in the sun, heart with nature. To nurture a garden is to feed not just the body, 
but the soul» byAlfred Austin and «The roots of all goodness lie in the soil of appreciation for goodness» by Dalai Lama ;

24) «The soil is the great connector of our lives, the source and destination of all." byWendell Berry, The Unsettling of America and «An optimistic gardener is one who believes that whatever goes down must come up» byLeslie Hall and «If a tree dies, plant another in its place. ». by Carl Linnaeus or «The greatest service which can be rendered any country is to add a useful plant to its culture. " byThomas Jefferson and «Gardening gives one back a sense of proportion about everything - except itself.» by May

Sarton;

25) «There is no gardening without humility. Nature is constantly sending even its oldest scholars to the bottom of the class for some egregious blunder. ». byAlfred Austin and «A garden is a grand teacher. It teaches patience and careful watchfulness; it teaches industry and thrift; above all it teaches entire trust». by Gertrude Jekyll

Besides above mentioned favourite twenty five students' phrases students were able to introduce into their speech such phrases as «You have to get up and plant the seed and see if it grows, but you can't just wait around, you have to water it and take care of it. » by Bootsy Collins or «Well I do find the beauty in animals. I find beauty everywhere. I find beauty in my garden. » by Doris Day or «I love being in my garden. I don't plant a lot of exotic flora, but I do spend a lot of time outside doing manual labour. » by Jacqueline Bisset as well as «My extravagance is my garden - it's the first thing I look at every morning when I wake up. It gives me so much pleasure. » by Ina Garten or «A garden is a complex of aesthetic and plastic intentions; and the plant is, to a landscape artist, not only a plant - rare, unusual, ordinary or doomed to disappearance - but it is also a color, a shape, a volume or an arabesque in itself. » by Roberto Burle Marx or "Let us not forget that the cultivation of the earth is the most important labor of man. When tillage begins, other arts will follow. The farmers, therefore, are the founders of civilization. " by Daniel Webster

The food for philosophical thinking is in statement «No one will understand a Japanese garden until you've walked through one, and you hear the crunch underfoot, and you smell it, and you experience it over time. Now there's no photograph or any 
movie that can give you that experience. » by J. Carter Brown too as well as within the expression«The most lasting and pure gladness comes to me from my gardens. " by Lillie Langtry or «To dwell is to garden. » by Martin Heidegger or «The more help a person has in his garden, the less it belongs to him. » by W. H. Davies as well as«All gardening is landscape painting. » by William Kent, «Flowers are happy things. » by P. G. Wodehouse, «Use plants to bring life. » by Douglas Wilson or «God Almighty first planted a garden. And indeed, it is the purest of human pleasures. " by Francis Bacon.

There also were the slogans to be represented by students in posters to be brought on English lessons using theses «The garden suggests there might be a place where we can meet nature halfway. " by Michael Pollan, "Trees and plants always look like the people they live with, somehow» by Zora Neale Hurston, «Weather means more when you have a garden. There's nothing like listening to a shower and thinking how it is soaking in around your green beans. » by Marcelene Cox, «I love planting. I love digging holes, putting plants in, tapping them in. And I love weeding, but I don't like tidying up the garden afterwards. » by Jamaica Kincaid, «A vegetable garden in the beginning looks so promising and then after all little by little it grows nothing but vegetables, nothing, nothing but vegetables. » by Gertrude Stein, «I also like to garden. I grow things, vegetables, flowers... I particularly like orchids. I raise orchids. " by Beau Bridges or «The garden, by design, is concerned with both the interior and the land beyond the garden. » by Stephen Gardiner «I value my garden more for being full of blackbirds than of cherries, and very frankly give them fruit for their songs. " by Joseph Addison as well as «I need my friends, I need my house, I need my garden. » by Miranda Richardson, «I like solitary pursuits, such as reading or pottering about in the garden. " by Hayley Mills, "Well tended garden is better than a neglected wood lot. » by Dixie Lee Ray or «Gardening requires lots of water - most of it in the form of perspiration. " by Lou Erickson, "Gardening is cheaper than therapy and you get tomatoes. » by unknown author and «In every gardener there is a child who believes in The Seed Fairy. » by Robert Breault. 
It's worth to announce that there were two teams to support of deny the statement «Gardening is a matter of your enthusiasm holding up until your back gets used to it. » by unknown author, «A garden is always a series of losses set against a few triumphs, like life itself. » by May Sarton, «The greatest gift of the garden is the restoration of the five senses. » by Hanna Rion or «There can be no other occupation like gardening in which, if you were to creep up behind someone at their work, you would find them smiling. » by Mirabel Osler and «In my garden there is a large place for sentiment. My garden of flowers is also my garden of thoughts and dreams. The thoughts grow as freely as the flowers, and the dreams are as beautiful. » by Abram L. Urban, «It is good to be alone in a garden at dawn or dark so that all its shy presences may haunt you and possess you in a reverie of suspended thought. " by James Douglas or «God made rainy days so gardeners could get the housework done. " by unknown author.

Moreover students recognized statements «Don't wear perfume in the garden — unless you want to be pollinated by bees. » by Anne Raver, «Plant carrots in January and you'll never have to eat carrots. » by unknown author, «Weather means more when you have a garden. There's nothing like listening to a shower and thinking how it is soaking in around your green beans. " by Marcelene Cox or «Gardens are a form of autobiography. » by Sydney Eddison to be practically oriented and similar to saying «Science, or para-science, tells us that geraniums bloom better if they are spoken to. But a kind word every now and then is really quite enough. Too much attention, like too much feeding, and weeding and hoeing, inhibits and embarrasses them» by Victoria Glendinning or «Many things grow in the garden that were never sown there. »Thomas Fuller and «Despite the gardener's best intentions, Nature will improvise.

Michael P. Garofalo and «Coffee. Garden. Coffee. Does a good morning need anything else? »byBetsy Cañas Garmon.

Moreover future biotechnologists and future agronomists involved into their lesson speech such interesting facts as «The hum of bees is the voice of the garden. »byElizabeth Lawrence, «Let nature be in your yard. » by Michael P. Garofalo, «To forget how to dig the earth and to tend the soil is to forget ourselves» by Mahatma 
Gandhi, «We have descended into the garden and caught three hundred slugs. How I love the mixture of the beautiful and the squalid in gardening. It makes it so lifelike. » byEvelyn Underhill, «Gardening is about enjoying the smell of things growing in the soil, getting dirty without feeling guilty, and generally taking the time to soak up a little peace and serenity» by Lindley Karstens, «Half the interest of a garden is the constant exercise of the imagination. » by Mrs. C.W. Earle,Pot-Pourri from a Surrey Garden, 1897 or «It was such a pleasure to sink one's hands into the warm earth, to feel at one's fingertips the possibilities of the new season. » by Kate Morton, «Anybody who wants to rule the world should try to rule a garden first. " by Gardening Saying and "In almost every garden, the land is made better and so is the gardener. » by Robert Rodale (1930-1990) as well as "If you have a garden and a library, you have everything you need. " by Cicero or "I know the pleasure of pulling up root vegetables. They are solvable mysteries.» by Novella Carpenter or «The single greatest lesson the garden teaches is that our relationship to the planet need not be zero-sum, and that as long as the sun still shines and people still can plan and plant, think and do, we can, if we bother to try, find ways to provide for ourselves without diminishing the world. " by Michael Pollan.

The complicated expressions being related to this topic may be regarded in such sentences as «Odd as I am sure it will appear to some, I can think of no better form of personal involvement in the cure of the environment than that of gardening. A person who is growing a garden, if he is growing it organically, is improving a piece of the world. He is producing something to eat, which makes him somewhat independent of the grocery business, but he is also enlarging, for himself.I think the true gardener is a lover of his flowers, not a critic of them. I think the true gardener is the reverent servant of Nature, not her truculent, wife-beating master. I think the true gardener, the older he grows, should more and more develop a humble, grateful and uncertain spirit. » byReginald Farrer» in parallel of existence of short phrases like «Farming is a profession of hope» by Brian Brett or «Life's a garden — dig it. » byGardening Saying or short German proverb «The garden is the poor man's apothecary.» 
And now it's a turn to represent important factor to develop future agrobiologists communicative skills are hand-made pictures or posters to predict real life story as well as searching interesting facts or humoristic stories. That material may be concluded on the first stages of communicative work and be used as the basis of the above mentioned dialogues but in their turn this material may be applied separately to enhance like «An apple tree grew on the field. The worm, wholived on a tree, ate an apple at lunchtime and lay down to rest. In hour later, it became bad. It was poisoned.

To establish the reason, it went to the lab. It gave an apple for to analyze.

The research was carried out using chemical and biological methods.They deter mined the chemical and genetic composition of the product and the presence of pests, taste and smell. The next day, it received a conclusion. In conclusion it was written genetically modified and resistant to insects. The apple tree was cut down and a new tree was planted. Can a genetically modified apple be poisoned?» or «Once upon a time Tim opened his e-mail and saw the letter. The letter was asking for help to solve the problem with the harvest. Tim agreed had happened. The problem was the small amount of harvest. Tim developed special organic fertilizers. To make them, he cloned genes and derived antigen. He also suggested the use of methyl iodide and potassium iodate. Thanks to Tim's help, the harvest resumed and became even greater» as well as "One evening Bill and Mary heard a loud noise and lantern light filled the room. They were frightened and decided to go to their field to find the reason out. The light was so bright that they could not see what was placed in front of strange object looking in general like UFO. But when agronomists came nearer they recognized familiar tractor driver and his tractor which was aimed to plow the fields per night to be ready for the next day raking, making seedbeds and fertilizing. Bill and Mary asked tractor drive to have a rest and promised to finish seedbed preparation together».

The other versions of such real life stories which attracted students' interest in developing professional speech on the basis of the everyday use speech were represented some notes. It was important to involve biotech students all levels of 
preparation. There were taken into consideration either simple stories with the elements of professional biotech speech «One day Sandra come to the laboratory and her manager told her to do on experiment with a rat. Sandra began to prepare for the experiment, opened a cage with a rat and suddenly she was called. While she was talking on the phone, the animal ran away. While Sandra was away, the rat ran, hooked the tail of the reagent, which spilled on her and died. So we'd come to conclusion: you need to monitor your work and not be distracted by phone calls, as this can lead to various annoyances» or «One day Alise went to the Lab. On an autumn day, the girl saw a leaf with various spots on the road. She was interested in it and she decided to find out what kind of disease on the leaf. Alice conducted research and identified the disease in the laboratory. It was a viral leaf disease that infected all the surrounding plants. Now Alice needs to figure out how to destroy this virus» or «One man was very fond of plants. He was a biotechnologist and interested in science. He had red hair and round glasses. But he was very lonely. No one wanted to be friend with him because he was crazy. In secret from everyone, he decided to make a friend. He knew about the technology CRISPR-Cas9. He decided to remove the cell wall of the rose. Then be cut out the required part of the gene and used the required complementary DNA. He went to sleep. The next morning he had a real friend. His rose smiled at him» as well as «One man was very fond of plants. He was a biotechnologist and interested in science. He had red hair and round glasses. But he was very lonely. No one wanted to be friend with him because he was crazy. In secret from everyone, he decided to make a friend. He knew about the technology CRISPR-Cas9. He decided to remove the cell wall of the rose. Then be cut out the required part of the gene and used the required complementary DNA. He went to sleep. The next morning he had a real friend. His rose smiled at him».

Besides first steps professional real life stories there were the examples of more complicated ones like "Once upon a time, there lived a young handsome man. His name was Ermine. He had long dark hair and painful sight. Many of citizens who had known him before would say that it was because of his character or his past, maybe it was true but only partly. The main reason was - he had been almost blind for years. 
But he wasn't an ordinary guy, he was a biotechnologist, a man who could create almost everything. He had spent many years studying how to recover his vision, and finally he found the answer. Every person had genes who were responsible for receptor synthesis in the eyes called rod cells and cones. He tried to manipulate with them, but there was no success. Ermine knew that he had to try on himself, at least it could probably lead to progress. Also, he realized that it might be dangerous up to his death, but he decided to take a risk, because it was better to be dead rather than blind or crippled for rest of his life. After some days preparing he injected the solution of photoreceptors right in his eyes and waited. The result was incredible, his eyes changed their color and he could see again, even better than he used to. Some of them could call him insane, the others - genius, but sometimes you have to take risk to achieve the result you expect» The another example is "Before maternity leave my mother had been working as a Business Development Manager in a big agricultural company. And I helped her to organize field day for farmers. I sent emails with invitation to more than 3000 farmers. And I answered to their questions and explained why it was important to visit this event. I was really very proud of myself because this field day was attended by more than 1000 farmers. It was very useful for them to know about new technologies of growing corn and sunflowers from market leaders such as DuPont, Pioneer, Syngenta, Basf» or «This funny but very instructive story happened to me during a practical lesson on biotechnology. I came to class with the freshmen and I had to cut a leaf. I took an iron scalpel and held it over the fire, but I couldn't cut the leaf. One of the freshmen advised me to use a plastic spatula, as it is sharper. I took a plastic spatula and put the iron scalpel back - and then there was a fire. Everyone was scared, of course, but the teacher quickly came up to us and covered scalpels with a glass. The incident was over, but we learned a lesson to follow the instructions».

It's worth to inform that the task concerning real life stories concluding became the favorite activity of every student undependly of their English and they might become the background of the previous first step dialogues. The examples of them may be introduced in such statements as «Good afternoon, nice to meet you! Hi, nice to meet you too. Can I help you?- Yes, you can. Let us discuss real life story concerning 
biotechnology.- I agree, with pleasure. What real life story do you mean?- Well, listen. Once upon a time there lived a lonely man. His name was Jack. His wife died after illness. He created attenuated vaccine against bovine spongiform encephalopathy because of wife's death of this disease. Jack has many problems with this vaccine. He could solve the puzzle, he just had to anneal the culture and create a cloned stain. Oh, poor Jack, if he could save her.-: Oh, that's a pity, but it's interesting too. And what professional terms did you apply in it?-: I applied such terms as chromosome and complementary DNA.- What do they mean?- For example, chromosome - s a long DNA molecule with either a part or the all of the genetic material of the organism. Complementary DNA is a DNA synthesized from a single-stranded RNA or mRNA template in a reaction catalyzed by the enzyme reverse transcriptase. Other terms are to be specified. - Thank you for your explanation. May I ask you more?- I'm afraid you're not. I'm short of time. We have to postpone our conversation. - I get it, see you later.- Bye»

These background dialogues in their turn became the background for the further transformation into more complicated ones to be represented earlier.

We consider represented dialogue work to be organic part each future dialogue participant should choose one the most actual problem within a certain field of agronomic knowledge, to narrow the circle of scientific interest in gathering facts and illustrations in relation to a particular theme for example concerning determining the features of biofuels potential [416]. On this stage each future dialogue participant should elaborate his own presentation concerning the general group topic with a detailed description of a certain latest equipment or technology that will be of interest either to professionals in a certain area of agrochemistry or to the general public. On this stage each future dialogue participant should print out the main points with illustrations and a vocabulary of basic concepts. This first step is considered to be very important preparatory stage for the further conclusion of dialogue in accordance with the colloquial situation «Your are the members of scientific society. Represent your scientific interest and describe the structure of your presentation» . 
The second step is to review the guidelines for selecting the second participant in the dialogue with identical scientific interest. At the specified stage of the discussion of achievements, two relevant presentations about biofuels must be concluded. Please, pay attention that their content, vocabulary should not be repeated by another future dialogue participant. For the implementation of the indicated instruction between these two future dialogue participants, the emphasis is to be placed on the use of such lexical units as «biofuels - біопаливо», «digestion - розщеплення», «residues - залишки, відходи», «soybean - соя», «pellets - гранули», «luтber - пиломатеріали», «сrops - зернові культури», «biodegradable - той, що розкладається природнім шляхом», «fossil-копалини», «recycled -перероблений», «етіssions-викиди», «feedstocks-сировина» etc. According to the task to discuss the value of biofuels, a plan of reports about biofuels for the first participant should be updated on such items as «1) Biofuels as a term»; «2) The sources to obtain biofuels»; «3) The difference between ethanol and biodiesel» and for the second participant it should be updated on such items as «1) The nature of biogas»; «2) Pallets»; «3) Liquids». Also the future dialogue participants should preview content of each presentation and they should prepare some previous answers to specific questions. The previous review of replicas to be checked by the first dialogue participant should predict such previous answer as «A biofuel is a fuel that is produced through biological processes, such as agriculture and anaerobic digestion, rather than a fuel produced by geological processes (coal or petroleum)» for the question «What are biofuels?». Besides, the context may be specified by the first student with the answer «Yes, it is» for the question «Is biological fuel a safe alternative to existing vehicle engines? 》 and «Biofuels technology is capable of reducing greenhouse gas emissions and for the use of fossil fuels, is not it? » as well as «Is biofuel produced from renewable biomass material, commonly used as an alternative, cleaner fuel source to burning fossil fuels? » and «Is it difference between ethanol and biodiesel?» with the appendix in answer like «Ethanol is a flammable and renewable liquid produced by the fermentation of grain or from advanced technology such as agricultural waste, wood chips and waste paper. And biodiesel is produced through a combination of alcohol with recycled cooking 
grease, animal fat or vegetable oil» and the answer «No, they are not» for the question «Are biofuels high in carbon intensity?». This first participator of discussion must choose the most interesting questions among the above named list to be asked. The second participant of the dialogue in his own turn must choose his own five the most interesting answers among the answer «The process of anaerobic digestion of organic material by anaerobes leads to biogas. The use of energy crops fed into anaerobic digesters to supplement gas yields» for the question «What leads to biogas?», the answer «Grain, crop residue, cellulosic crops (e.g., switch grass, sugar canes and various tree species) are used for the production of biofuel. These products are processed further to generate liquid fuels such as ethanol or diesel fuel. These fuels release $\mathrm{CO} 2$ when burned, but this $\mathrm{CO} 2$ is of recent atmospheric origin (via photosynthesis) and displaces $\mathrm{CO} 2$ which otherwise would have come from fossil carbon» for the question «What materials are used to produce biofuels?» and the answer "They may be in solid form like pellets in gaseous form like biogas and in liquid state as biodiesel» for the question «What are the main kinds of biofuels?» as well as the answer «They are usually made from compressed industrial waste and coproducts, food waste, agricultural residues, lumber, energy crops» for the question «What are the features of pellet fuels (or pellets)?».

The next stage is to transform common dialoque into discussion. Following it every participant must get positive or negative attitude to biofuel usage choosing arguments among advantages or disadvantages. The first discussion participant may choose his arguments by shotering the provement of advantges on his own mind: «Unlike fossil fuel, biofuels are produced from renewable resources. Also there are less pollutant emissions from biofuels. Ethanol reduces carbon monoxide emissions as it ensures complete combustion. Besides, biofuel do not contribute to global warming as carbon dioxide released, is taken up by their feedstocks. There are also some advantages in some statements like biofuels are cost-efficient when compared to fossil fuels and some of the biofuels producing plants like Jatropha and oil-palms can be grown in dry land and fallow area. Also about 70-88 million biogas plants can be run with fresh/dry biomass residues. The substrate such as cattle waste and biomass used 
for this technology are easily available. Their availability to biogas plants can meet the requirement of 12-30 million families. The calculated global potential of biogas production is in theory sufficient to cover up to one-fourth of the present consumption of fossil fuels within the global transport sector. Using it within agriculture could reduce agriculture's dependency on fossil energy, improving food security. Making biofuels is a profitable process not only for the economy but for the environment. We can use this kind of fuels for agricultural machinery».

The second discussion participant may choose his arguments by shotering the provement of disadvantges on his own mind: «A larger area of land will be required to satisfy global biofuels demand. Projected growth of biofuels crops until 2030 may require over 30 million hectares of land. In many cases for current ethanol production from grain, the fossil fuel associated with use of chemical fertilizers, tractor power and so on, results in an unacceptably small net reduction in fossil fuel use. Besides, production systems with suitable enzymes for utilizing cellulosic feedstocks have not yet become commercially viable. Also it should be mentioned that the resources for biogas generation are not properly managed to generate its maximum biogas potential. Besides, the lack of availability and the structural operation of biogas digesters are not able to generate and develop family-size biogas plants. Despite our country has many resources to create a biofuels but we have some problems with funding» .

The next stage to involve English expressions into dialogue- discussion should be immediate introduction of it, starting with the indication of their roles, the greetings and the purpose of the communication: definition in such phrases as «I'm one member of scientific (sphere of knowledge) society and you are another scientist», «Hello. Nice to meet you», «Hi, nice to meet you too. Can I help you?», «Yes, you can. Let us discuss our reports», «You are welcome. What are you interested in?». On this stage future dialogue participants should be guided by a thematic approach to involve common English statements with some spaces for continuation basing upon explanation in brackets : «What is your scientific interest?», "I'm interested in (the title of presentation)», "What is the structure of your report?», "It is in the form of presentation to include ( quantity) slides», «What is your plan?», «The main points are 
(noting the points of the plan of the pre-prepared presentation)», "What are your main terms from vocabulary?», "They are (preprepared vocabulary)», "What are the most actual phenomenon to be represented?» (noting the title of preprepared presentation), «What are their usage and advantages?» noting advantages from preprepared explanation), «They are (preprepared theses) 》, «Is your topic important?», «Yes, it is. It is important because (explanation involving the answers to preprepared questions)》.

The elements of discussion may predict such phrases as «I'm afraid I can no agree», Is it good for environmental safety?» etc. The next stage is the reversible answering to specify the unannounced points by involving some English statements to be prepared by the second dialogue participant with the pre-stage addition «Will you be so kind to explain the specific points like the forms of biofuels?»

The seventh stage is to require the completion of the conversation in certain statements like «Well, I'm interested in your report», «Thanks for your interest. Your report is important too. See you while reporting», «Bye» to finish conversation.

The eight stage deals with philological studies here is a problem of supplementing the points of analysis of terms and practical analysis of the term «Agronomy» as a basis for research in both the field of linguistic and agrobiological field of knowledge in the implementation of linguistic studies in practical classes in English for professional purposes as well as the problem of comprehensive analysis of terms being related to the agrobiological field of knowledge. The basic approaches to the analysis of terms in general include eight items like: 1) by word origin; 2) by the scope of use; 3) by the number of parts in pronunciation; 4) by the number of letters, sounds and accents; 5) by parts of speech; 6) by the presence of synonyms and cognate words; 7) by stylistic features and the degree of general use; 8) the possibility of forming new terms in order to eliminate homonymy. It is proposed to supplement the list of analysis of terms with the category «Related foreign terms». An example of practical analysis in accordance with these categories is given with an addition. Actually the description of the term «Agronomy» according to the named general approaches and our addition looks as follows:1) (from agro... and Greek nómos-law), literally the science of the laws of agriculture, in a broad sense - the scientific basis; 2) 
use in professional speech among employees of agricultural companies, in advertisements and newspapers of the Ukrainian-speaking mentality; 3) the multisyllable is uncovered, because it has as many as five syllables and begins and ends in the same way with a loud sound; 4) 9 letters, 10 sounds -5 consonant sounds and 5 vowel sounds, the fourth syllable is stressed (of which vowel, unstressed - 4 representatives, consonant, hard, sonorous -3 representa-tives, vowel, stressed -1 representative, consonant, soft, sonorous - 3 representatives); 5) Agro, nom - roots, and-suffix, I - ending, agronomist - the basis of the word; 6) synonyms (horticulture, botany, meteorology, geodesy, selectivity, etc.), cognate words (agroclimate, agrocenosis, agrochemistry, agro-industry, agropolitics); 7) refers to the scientific style being used in scientific articles to describe technological processes, schemes, construction of plans, etc. Belongs to the class of professionalism in the field of science, production, fishing etc.; 8) analogues include such terms in one word or word combinations like land management, horticulture, agricultural production,etc.; 9) related foreign language terms: blossom - цвim, branch - галузь або гілка, broadcast seeding - трансмісійний висів, biennials - дворічні рослини, bисkwheat - гречка, bud - брунька; cabbage - капуста, cauliflower - цвітна капуста, сапе - стебло або тростина, cell - клітина, cereals - зернові, clay- глина, combine harvesting механізоване збирання врожаю еtс

The stage of the detailed description of the nesting phenomenon and making descriptive notes. On this stage the students have investigated that morpheme landis mainly nested in more than one hundred varieties exampling thirty five basic varieties and seventy four additional varieties [415]. Morpheme land- is mainly represented in following thirty five basic varieties: nine attribute-noun two components word combination (leased land,degradated land, sold land, purchased land, arable land, dry land, bad lad, fertile land, land measuring), one attribute-noun three components word combinations(land natural resources), two noun-noun three components word combinations (land cost definition, forest plants land, water fund land, land reconnoitre observation), sixteen two components noun-noun word combinations (land purpose, land quality, land administration, land recultivation, land 
cadastre, land domain, land estimation, land easement, land tax, land evaluation, land law, land melioration, land relief / terrain), land measurements, land redistribution, land surface), three multistructural word combinations etc.

In general it was distinguished that morpheme land- includes either 35 basic varieties (land, leased land, degradated land, sold land, purchased land, arable land, dry land, bad land, fertile land, land measuring, land natural resources, land cost definition, forest plants land, water fund land, land reconnoitre observation, land purpose, land quality, land administration, land recultivation, land cadastre, land domain, land estimation, land easement, land tax, land evaluation, land law, land melioration, land relief / terrain, land measurements, land redistribution, land surface, land of natural reserve and other nature conservation purposes, land of residential and public buildings, land of sanitary purpose). Besides, morpheme land-includes 74 additional varieties being included into 13 derivative compounds (land plan, land manager, land management, land code, land parcel, land plant, land use, land property, land samples, land probing, land crops, land owner)which have become nesting items themselves because of the regular usage for land management texts in such representation. The most nesting morpheme morpheme land- derivative compounds are land management, land plot, land parcel and land crops to be used together with 35 morpheme land- basic varieties for the future dialogue concluding on the basis of the shortened list of professional phrases. The majority of morpheme land- nesting varieties belongs either to noun-noun two components word combination or to attribute- noun two components word combinations. The majority of morpheme land- derivative compounds belong either to attribute- noun three -four component word combinations or to noun-noun three-four component word combinations. The main stages of linguistic must predict three previous stages like the stage of the agrobiologists' adapted foreign texts reading and analysis concerning searching landmorpheme representatives, the stage of the detailed description of the nesting phenomenon and making descriptive notes and the stage of making mathematic calculations, table columns context coding and adequate statistic linguistic tables concluding. The prospect of research is to observe a range of concrete real life 
communicative situations on the basis of the previously distinguished common adequate morpheme land- word combinations.

In our opinion, the submitted order of English statements involvement optimized the work of agrobiological direction students while preparation for discussion of reports-presentation of the latest technologies in the relevant field of knowledge. The experience to involve the above named algorithm may be considered to be successful because of the adequate questionnaire in which students evaluated such experience as positive to adapt them to foreign speech.

It's worth to say that real life stories concluding attracted either not advanced level students'interest starting from short stories like «The agronomist came to the field. He began to examine the state of winter wheat. He saw that there were too many pests on plant leaves. He consulted with the nearby farm agronomist. They decided to spray the field. A tractor arrived on the field. The pests were killed» and ending the advanced level wide stories: «Peter Johnson at wheat Pete real agriculture calm and its wheat planting season it's awesome I love it what are we doing wrong why does always have to be what are we doing wrong but we are doing some things that we really have to step back and question so first off biggest question of the season right now how deep do I plant my wheat and why is that the question because it is dry not everywhere in fact amazing the sweet spot of Ontario 74 bushel per acre soybeans planted wheat the day after those soybeans came off and four days later the wheat was out of the ground can you imagine that but they've got good moisture lots of areas very dry so here's the scenario either we have to plant deep to go to moisture or we plant in dust and get over this concept leave it in the dag till it rains that's all bad because once it starts to rain it may never stop and if it's in the ground at an inch and a quarter I like an inch but an inch and a quarter then once it rains it will start to grow so whatever you do plant the stinking wheat but if you plant at an inch and a quarter and you say l'll wait it rains yeah who knows when that'll be that might in fact go back far enough there was a grower who did that and his wheat emerged under the snow at Christmas time because it didn't rain until the end of October in Essex County that year if you can get to moisture that's the right choice so it's kind of interesting because we always talk lots 
about how deep can you plan and with soybeans in the spring we tell you don't go over two inches because that hypocotyl it doesn't extend enough and they won't emerge well if you remember Act two we talked about double crop soybeans when we plant double crop soybeans we can plant those three three and a haif inches deep and because the soil is so warm that hypocotyl elongation is way bigger same thing early in the fall it's warm so whereas normally I don't want you to plant three inches deep if you can find moisture at three inches deep plant three inches deep and it's so warm that even though it takes a little more heat to get that wheat out of the ground it'll still bounce out of the ground really really quickly and you'll have a nice even stand and you'll have way more yield because we've learned that yield is all about planning date so it's quite clear we have a big variability in this field in terms of where that's the stage of development side some of the wheat is already coming into the to leaf stage here I have nothing at all and what's going on here when we start to dig down and gosh we can see that no week that wheats not anywhere near deep enough and so this is the crux of the issue you really have to get this wheat in to moisture now it's interesting it is winter wheat and people say you know with with soybeans they need four times their weight in water to to germinate and with corn it needs at least twice its weight in water remember how easily wheat will gain moisture in the summertime when you're trying to combine the doggone stuff and it's 14 percent moisture or it's 16 percent moisture at 6 or 8 o'clock at night you shut the combine down and it's a heavy dew over night what's it go to 19 percent moisture 20 percent moisture so wheats a different beast it doesn't need a ton of moisture but it needs some moisture so actually wheat will germinate there's some research out there that says if you just can get into a humid environment you don't need real moisture you need just high humidity it will germinate and grow but if you put it into this dust and this is a pulled and wind road edible bean field and so they've dried it out a fair bit you don't get it deep enough then you don't get a stand so get that drill deep and that wheat up and growing a couple of other really really important things about this at this particular harvest and I see it again it drives me absolutely nuts residue spread what is the matter how many times you have to talk about this and so you can see here we've got six feet with no residue and we've got 24 
feet with residue that's not good enough it's not going to do the job that we want and the other one is weed control weed control this kaleipus eight resistant fleabane either you spray it with Aragon with your roundup before the week gets up or you spray it with infinity once the wheat is up they're both registered they'll both take out fleabane this year it's been another big challenge for us it's one of those things we can't let go meanwhile get the wheat in the ground get it deep enough to get it up and let's break out previous record grow wheat Peter Johnson at weed Pete real agriculture calm».

Thus, the abovenamed experiment within the National University of Life and Environmental Sciences of Ukraine during the first 2021/2022 studying year term including participation of bachelor's degree program 88 students from the Agrobiological Faculty and the Faculty of Plant Protection, Biotechnology and Ecology showed the adequacy of real life dialogues, humoristic stories and interesting facts application in combination with the parallel professional speech introduction while studying and discussing GMO, bioengineering, seeds, soil, plant growth, agricultural products and processes etc basing upon background of traditional tasks to be in general part of such seven stages of students' foreign speech development as) familiarization and narrowing of the actual professional topics to general one, at which simultaneously several reports are prepared; 2)clarification of the plan, vocabulary, key questions and answers of each of the participants in the future dialogue to avoid coincidences; 3) preliminary formal general dialogue start with constant colloquial cliché; 4) the actual entry into the dialogue according to a specific topic; 5) providing dialogue with the elements of the discussion; 6) a reversible asking to specify unpublished pre-prepared items; 7) the formal general ending of the conversation with the stable conversational clichés(0therminological work, the work with proverbs and statements by great writers and scientists as well as state figures which involve professional biotechnologists' and agronomists' vocabulary and speech mentioning the topics of the most students' interest. In our case the topic «Soil» was elaborated in 11 versions and plant «Growth» in nine versions of students' dialogues.

The perspective of investigation is the description of the practical experiment to develop communicative skills of future technicians in details. In parallel it's important 
analysis of the activity of fulfillment, the correctness of content design and understanding of the set tasks either aiming to represent general and personal recommendations to improve gaps in freshmen's foreign language knowledge, abilities and skills or further correction of topical content of studying course being based on the real future agronomists' and biotech students' demands 